\title{
A re-evaluated Canadian ozonesonde record: measurements of the vertical distribution of ozone over Canada from 1966 to 2013
}

\author{
D. W. Tarasick ${ }^{1}$, J. Davies ${ }^{1}$, H. G. J. Smit ${ }^{2}$, and S. J. Oltmans ${ }^{3}$ \\ ${ }^{1}$ Environment Canada, 4905 Dufferin Street, Downsview, Toronto, ON, M3H 5T4 Canada \\ ${ }^{2}$ Institute for Energy and Climate Research: Troposphere (IEK-8), Research Centre Juelich (FZJ), Juelich, Germany \\ ${ }^{3}$ Global Monitoring Division, Earth System Research Laboratory, National Oceanic and Atmospheric Administration, \\ Boulder, Colorado, USA
}

Correspondence to: D. W. Tarasick (david.tarasick@canada.ca)

Received: 25 February 2015 - Published in Atmos. Meas. Tech. Discuss.: 21 May 2015

Revised: 4 December 2015 - Accepted: 15 December 2015 - Published: 25 January 2016

\begin{abstract}
In Canada routine ozone soundings have been carried at Resolute Bay since 1966, making this record the longest in the world. Similar measurements started in the 1970s at three other sites, and the network was expanded in stages to 10 sites by 2003 . This important record for understanding long-term changes in tropospheric and stratospheric ozone has been re-evaluated as part of the SPARC/IO ${ }_{3} \mathrm{C} / \mathrm{IGACO}-\mathrm{O}_{3} / \mathrm{NDACC}\left(\mathrm{SI}^{2} \mathrm{~N}\right)$ initiative. The Brewer-Mast sonde, used in the Canadian network until 1980, is different in construction from the electrochemical concentration cell (ECC) sonde, and the ECC sonde itself has also undergone a variety of minor design changes over the period 1980-2013. Corrections have been made for the estimated effects of these changes to produce a more homogeneous data set.

The effect of the corrections is generally modest. However, the overall result is entirely positive: the comparison with co-located total ozone spectrometers is improved, in terms of both bias and standard deviation, and trends in the bias have been reduced or eliminated. An uncertainty analysis (including the additional uncertainty from the corrections, where appropriate) has also been conducted, and the altitudedependent estimated uncertainty is included with each revised profile.

The resulting time series show negative trends in the lower stratosphere of up to $5 \%$ decade $^{-1}$ for the period 1966-2013. Most of this decline occurred before 1997, and linear trends for the more recent period are generally not significant. The time series also show large variations from year to year. Some of these anomalies can be related to cold winters (in
\end{abstract}

the Arctic stratosphere) or changes in the Brewer-Dobson circulation, which may thereby be influencing trends.

In the troposphere, trends for the 48 -year period are small and for the most part not significant. This suggests that ozone levels in the free troposphere over Canada have not changed significantly in nearly 50 years.

\section{Introduction}

Ozone plays a major role in the chemical and thermal balance of the atmosphere. It controls the oxidizing capacity of the lower atmosphere via its photochemical link to the $\mathrm{OH}$ radical and also acts as an important short-lived climate forcer. Ozone changes in the stratosphere, as well as strongly affecting surface UV radiation, may also affect future climate (IPCC, 2013, and references therein). In addition to the information they provide on the vertical distribution of ozone in the lower stratosphere, ozone soundings are the major source, worldwide, of information on ozone amounts in the free troposphere.

Vertical distribution information is particularly important for ozone transport studies, as motion in the atmosphere is predominantly horizontal. The global ozonesonde record is therefore increasingly important for understanding long-term changes in both tropospheric and stratospheric ozone, as each may be affected by changes in long-range quasi-horizontal transport, as well as by vertical exchange/mixing between layers. For example, ozonesonde measurements show impact on near-surface ozone concentrations of intrusions of ozone 
Table 1. The Canadian ozonesonde network. Soundings are weekly (generally Wednesdays), with extra releases during special campaigns (i.e. MATCH, TOPSE, IONS, BORTAS). Regular ozone soundings have been made at Resolute since January 1966.

\begin{tabular}{llll}
\hline Station & Location & Altitude $(\mathrm{m})$ & Start of sonde record \\
\hline Edmonton & $53.6^{\circ} \mathrm{N}, 114.1^{\circ} \mathrm{W}$ & 766 & Brewer-Mast (1970); ECC (1979) \\
Goose Bay & $53.3^{\circ} \mathrm{N}, 60.3^{\circ} \mathrm{W}$ & 44 & Brewer-Mast (1969); ECC (1980) \\
Churchill & $58.8^{\circ} \mathrm{N}, 94.1^{\circ} \mathrm{W}$ & 35 & Brewer-Mast (1973); ECC (1979) \\
Resolute & $74.7^{\circ} \mathrm{N}, 95.0^{\circ} \mathrm{W}$ & 64 & Brewer-Mast (1966); ECC (1979) \\
Eureka & $80.1^{\circ} \mathrm{N}, 86.4^{\circ} \mathrm{W}$ & 10 & ECC (1992) \\
Alert & $82.5^{\circ} \mathrm{N}, 62.3^{\circ} \mathrm{W}$ & 62 & ECC $(1987)$ \\
Kelowna & $49.9^{\circ} \mathrm{N}, 119.4^{\circ} \mathrm{W}$ & 456 & ECC (2003) \\
Bratt's Lake & $50.2^{\circ} \mathrm{N}, 104.7^{\circ} \mathrm{W}$ & 580 & ECC $(2003-2011)$ \\
Egbert & $44.2^{\circ} \mathrm{N}, 79.8^{\circ} \mathrm{W}$ & 251 & ECC $(2003-2011)$ \\
Yarmouth & $43.9^{\circ} \mathrm{N}, 66.1^{\circ} \mathrm{W}$ & 9 & ECC (2003) \\
\hline
\end{tabular}

from the lower stratosphere (e.g. He et al., 2011; Hocking et al., 2007) and the inter-continental transport of tropospheric ozone and its precursor species (Oltmans et al., 2006, 2010). Canadian ozonesondes have also provided essential information on the nature of Arctic stratospheric ozone loss (Manney et al., 2011; Fioletov et al., 1997; Kerr et al., 1993), of Arctic surface depletion events (Tarasick and Bottenheim, 2002; Bottenheim et al., 2002), and of the global circulation of ozone (Lin et al., 2015; Bönisch et al., 2011; Pan et al., 2009), as well as of tropospheric sources and budgets (Emmons et al., 2015; Parrington et al., 2012; Walker et al., 2010, 2012; Macdonald et al., 2011; Thompson et al., 2007; Tarasick et al., 2007).

The time series of ozone soundings from Canadian stations comprise some of the longest records of vertical ozone profile measurement that exist, as well as the only time series of measurements in the free troposphere over Canada. Following some initial ozone soundings conducted in cooperation with the US Air Force Cambridge Research Laboratories (AFGL) from 1963 to 1965 at Goose Bay and Churchill, employing chemiluminescent (Regener, 1960) sondes (Hering, 1964; Hering and Borden, 1964, 1965, 1967), regular ozone soundings using electrochemical Brewer-Mast sondes (Brewer and Milford, 1960) began at Resolute in January 1966. Table 1 describes the locations of Canadian ozonesonde stations and their data records.

Preparation procedures for the Brewer-Mast sondes are described in Tarasick et al. (2002) but essentially followed Mueller (1976). In 1980 the Canadian network switched to electrochemical concentration cell (ECC) sondes (Komhyr, 1969). ECC sonde preparation and launch procedures are as described in Tarasick et al. (2005). Although these procedures were not changed at any time in the Canadian record, the change of sonde type, as well as minor changes in the design of the ECC sonde over the past 3 decades, may have introduced biases in the measurement time series that could affect trends (Table 2). The associated radiosonde has also changed, which could influence the ozone profile by intro- ducing altitude shifts, primarily above $25 \mathrm{hPa}(25 \mathrm{~km})$, due to temperature or pressure biases.

As part of the SPARC/IO 3 C/IGACO-O $3 / \mathrm{NDACC}\left(\mathrm{SI}^{2} \mathrm{~N}\right)$ initiative, the Ozonesonde Data Quality Assessment (O3SDQA) was initiated in order to resolve inhomogeneities in the global long-term ozone sounding record. The effects of many of the changes listed in Table 2 have been characterized by recent laboratory and field work and can now be corrected. The uncertainty of ozonesonde profile measurements can now also be described with a degree of confidence that was not available in the past. These developments are described in a recent report (Smit et al., 2012), and the re-evaluation of the Canadian record described here follows those recommendations.

\section{Corrections to the sounding data}

The operating principle of electrochemical ozonesondes is the well-known reaction of potassium iodide with ozone:

$2 \mathrm{KI}+\mathrm{O}_{3}+\mathrm{H}_{2} \mathrm{O} \longrightarrow 2 \mathrm{KOH}+\mathrm{I}_{2}+\mathrm{O}_{2}$

followed by

$\mathrm{I}_{2}+2 e^{-} \longrightarrow 2 \mathrm{I}^{-}$.

Thus for each molecule of ozone two electrons are produced and an equivalent amount of current flows through the external circuit. The measurement is therefore, in principle, absolute; however, there may be losses of ozone and/or of iodine, and there may be side reactions that also convert iodide to iodine. Ozone partial pressure is calculated using the ideal gas law, noting from Reaction (R2) that the number of moles per second of ozone passing through the sonde is equal to half the current divided by the Faraday constant. This gives (e.g. Komhyr, 1986)

$P_{O_{3}}=k\left(i-i_{\mathrm{B}}\right) T t$,

where $i$ is the measured cell current, $i_{\mathrm{B}}$ is the background current, $T$ is the temperature of the air in the pump (often ap- 
Table 2. Changes in ozonesondes and associated radiosondes in the Canadian network.

\begin{tabular}{lll}
\hline Year & Change & Possible effect \\
\hline 1979 & ECC 3A introduced & $\begin{array}{l}\sim 15 \% \text { increase in tropospheric response relative to BM sondes. } \\
\text { Sonde } T \text { measured via rod thermistor. }\end{array}$ \\
\hline 1984 & ECC 4A introduced & $\begin{array}{l}\text { Redesigned pump; maximum change }<1 \%, \text { at } 50-20 \mathrm{hPa} . \\
\text { Sonde "box" } T \text { measured; new rod thermistor. }\end{array}$ \\
\hline 1993 & ECC 5A introduced & New pump correction; maximum change $\sim 1 \%$, at $100 \mathrm{hPa}$. \\
\hline 1993 & Vaisala RS-80, RSA-11 introduced & $\begin{array}{l}\text { Older VIZ sonde: warm bias in daytime; pressure errors. } \\
\text { May introduce altitude shifts in profile; ozone increases of up to } \\
2 \%\end{array}$ \\
\hline 2000 & ENSCI 1Z design change & No differences below about 20-25 km (Smit et al., 2007). \\
\hline 2004 & 3cc solution (new sites) & High bias with 1\% KI solution (Smit et al., 2007). \\
\hline 2006 & Vaisala RS-92 introduced & Better ozone capture in troposphere. \\
\hline 2007 & Thermistor in ECC pump & $\begin{array}{l}\text { RS80s low by } \sim 20 \mathrm{~m} \text { in the troposphere, high by } 100 \mathrm{~m} \text { at } \\
10 \mathrm{hPa} \text { (Steinbrecht et al., 2008). }\end{array}$ \\
\hline
\end{tabular}

proximated by the sonde box temperature), and $t$ is the measured time in seconds for the sonde to pump $100 \mathrm{~mL}$ of air. $k$ is a constant, equal to 0.0004307 for current in microamperes, $T$ is in kelvins, and ozone partial pressure is in millipascals. Errors or bias changes in the temperature or background current measurement or the pump rate (or its change with ambient pressure during flight) can therefore affect the ozonesonde measurement.

\subsection{Total ozone normalization}

In practice ECC ozonesondes have a precision of 3-5\% and a total (random + systematic) uncertainty of about $10 \%$ throughout most of the profile below $\sim 28 \mathrm{~km}$ (Smit et al., 2007; Kerr et al., 1994; Deshler et al., 2008a; Liu et al., 2009). The precision of the older Brewer-Mast sonde is somewhat poorer, at about 5-10\% (Kerr et al., 1994; Smit et al., 1996). The Brewer-Mast soundings required normalizing, or "correcting", by linearly scaling the entire ozone profile (plus an estimate of the residual above the balloon burst altitude) to a total ozone measurement. This was because they showed a typical response equivalent to about $80 \%$ of the actual ozone amount when prepared according to the manufacturer's instructions (the Canadian practice) and so needed to be scaled, by what is traditionally referred to as the "correction factor", to give a more accurate result. Although the ECC sonde response is much closer to $100 \%$, normalizing to a coincident Brewer or Dobson spectrophotometer measurement has continued to be the Canadian practice because it demonstrably reduces uncertainties in ozonesonde data, at least in the stratosphere (e.g. Kerr et al., 1994; Smit et al., 1996; Beekmann et al., 1994, 1995). Averaged over the profile, uncertainties are $7-10 \%$ for non-normalized data and 5-7\% for normalized data (Fioletov et al., 2006). This improvement is because of the greater accuracy of total ozone measurements: for well-calibrated total ozone instruments the standard uncertainty of direct sun measurements is less than $3 \%$ (Basher, 1982).

The Canadian total ozone record has been extensively revised, but these revisions had not, until now, been carried through to the older ozonesonde records. This meant that the total ozone value in the sonde record (used for calculating the normalization factor) was frequently not the same as the revised value in the World Ozone and Ultraviolet Radiation Data Centre (WOUDC). We found occasional cases of surprisingly large differences $(\sim 35 \%)$. In some cases, particularly in the older Dobson record, a total ozone value for the previous day appears to have been used. In addition, historical practice in Canada for estimating the residual ozone amount above the profile top has been to simply assume constant ozone mixing ratio above the balloon burst altitude. Much better knowledge now exists for the distribution of ozone at higher altitudes, and so the use of a climatological estimate is preferred. We have used the climatology of McPeters and Labow (2012) to renormalize the Canadian data. The total ozone normalization is applied only after all other corrections have been applied (to the nonnormalized data; that is, any previous normalization is first removed). Normalization is not applied to flights that fail to reach $32 \mathrm{hPa}$. This is also a change from previous practice, which required flights to reach $17 \mathrm{hPa}$ for total ozone normalization to be applied.

There are arguments against normalization of ECC sonde profiles: the process introduces a degree of uncertainty be- 
cause the amount of ozone above the balloon burst height can only be estimated. It is also not clear that a scaling factor that is constant with altitude is appropriate in all cases. This is of particular concern for the tropospheric part of the profile; whether normalization, which is necessarily weighted to the much larger stratospheric part of the profile, improves tropospheric measurements is an open question. Normalization also renders the sonde record no longer independent of the total ozone record, which is an important issue for trend studies (although to some extent alleviated if there is no trend in scaling factors) and obviously can introduce a serious bias if the total ozone instrument calibration is in error. Fortunately, since the scaling is linear in measured ozone, it can be applied, and as easily removed, in post-processing or by the data user.

The normalization factor is unquestionably of value as a data quality control indicator, and we will use it as such in the analysis to follow. We present here normalized data, for consistency between the Brewer-Mast and ECC records, and with past trend analyses (e.g. Tarasick et al., 2005).

\subsection{Correction for Brewer-Mast tropospheric response}

Laboratory work (Tarasick et al., 2002) suggests that the response of Brewer-Mast sondes in the Canadian program was biased low in the troposphere. We have applied a correction based on simple quadratic fit to the data shown in Fig. 7 of Tarasick et al. (2002). The correction is consistent with that implied by the WMO-II intercomparison of 1978 (Attmannspacher and Dütsch, 1981; see also Fig. 10 of Liu et al., 2013) and also similar to, but somewhat more modest than, that suggested by the WMO-I and BOIC sonde intercomparison campaigns (Attmannspacher and Dütsch, 1981; Hilsenrath et al., 1986) and the analysis by Lehmann (2005) of Brewer-Mast data from the Australian program. The Australian program used similar procedures to those in Canada.

\subsection{Pump corrections}

The efficiency of the ozonesonde pump decreases at low pressures, and a correction for this is part of normal data reduction. Pump corrections from Komhyr et al. (1968) were used for Canadian Brewer-Mast sonde data (Mateer, 1977). We have now applied the more commonly used Komhyr and Harris (1965) pump corrections, recommended by WMO (Claude et al., 1987), which are larger than the Komhyr et al. (1968) corrections. Significantly larger pump corrections have been recommended by Steinbrecht et al. (1998), but these may not apply to older Brewer-Mast sondes (Lehmann and Easson, 2003).

For ECC model 3A sondes, flown in Canada between 1979 and 1982, no change to the pump correction has been made, but the pump correction table has been added to the file. The correction is that supplied by the manufacturer but also similar to that found by Torres (1981).
The ECC model 4A sonde differs significantly from the $3 \mathrm{~A}$; the major difference is a redesigned pump. In the original data reduction the correction curve supplied in 1983 by the manufacturer was used for all 4A flights. We have now applied the revised Komhyr (1986) correction curve. This correction curve was already in use for $5 \mathrm{~A}$ and all subsequent ECC sonde models. The pump correction table has been added to the WOUDC file for all flights.

\subsection{Solution volume correction}

Standard practice in Canada has been to charge ECC sensors with $2.5 \mathrm{~mL}$ of sensing solution rather than the $3.0 \mathrm{~mL}$ which is now recommended. Laboratory and field investigations have shown that with $2.5 \mathrm{~mL}$ of sensing solution only $\sim 96 \%$ of the ozone is captured by the sensing solution at ground pressure, but at lower pressures the $4 \%$ deficit vanishes, apparently because of faster gas-diffusion rates in solution (Davies et al., 2003). We have made a correction for this effect, following Smit et al. (2012).

\subsection{Use of standard $1 \%$ buffered-KI solution in ENSCI sondes}

Two types of ECC ozonesondes have been in use since about 2000: the $2 Z$ model manufactured by ENSCI Corp. and the 6A model manufactured by Science Pump, with differences in construction and in recommended concentrations of the potassium iodide sensing solution and of its phosphate buffer (Smit et al., 2007). Since the Canadian network has used standard $1 \%$ buffered-KI solution at all times, where ENSCI sondes have been used a positive bias of about $4 \%$ below $50 \mathrm{hPa}$ and somewhat larger above is expected (Boyd et al., 1998; Smit et al., 2007; Deshler et al., 2008b). We have made a correction for this bias, following Smit et al. (2012).

\subsection{Pump temperature measurement}

The measurement of pump temperature is required to accurately measure the amount of air passing through the pump into the ECC sensor cell. In the past this has been approximated by a measurement using a rod thermistor at the base of the electronics unit ( $3 \mathrm{~A}$ and $4 \mathrm{~A}$ sondes) and later a thermistor suspended in the sonde box. Field and laboratory experiments suggest that this produced a consistent relationship between the "box" temperature and the pump body temperature (Komhyr and Harris, 1971). Measurement of the actual pump temperature only became standard in Canada around 2008. We have made corrections for temperatures measured by either "rod" or "box" thermistors following Smit et al. (2012).

\subsection{Background current}

The background current of the ECC sonde is not well understood and may have several sources. It represents a nonequilibrium condition in the cell, possibly from residual tri- 
iodide in new sensing solution (Thornton and Niazy, 1982, 1983) or from previous exposure to ozone (Johnson et al., 2002). Canadian practice has been to treat it as proportional to pressure, but there is no reason now to think that this is correct, and treating it as approximately constant over the duration of a flight may be a better approximation and is in fact recommended (Smit and ASOPOS panel, 2011). Unfortunately to properly recalculate ozone assuming a constant background current requires knowledge of the pump temperature profile, and this information has been preserved only for flights after 1999. We have therefore not attempted to correct the background current but have instead treated it as an error source (see Sect. 4), a not entirely satisfactory choice, since although randomly variable in magnitude, it is always a positive bias.

\subsection{Radiosonde changes}

Errors in radiosonde pressure or temperature will imply corresponding errors in calculated geopotential heights, causing measured ozone concentrations to be assigned to incorrect altitudes and pressures. This is potentially an important issue for the derivation of trends, as radiosonde changes may therefore introduce vertical shifts in the ozone profile, and apparent changes in ozone concentration at a given height.

A number of different radiosonde designs have been used in the Canadian observing network over the last 5 decades. Temperature differences between the VIZ sonde, used widely in the 1980s and early 1990s, and the Vaisala RS-80 sonde, adopted subsequently in Canada, are well documented. The VIZ sonde showed a warm bias in the daytime by as much as $2{ }^{\circ} \mathrm{C}$ (Richner and Philips, 1981; Luers and Eskridge, 1995; Wang and Young, 2005). From simultaneous measurements made during a WMO intercomparison in 1985 , Schmidlin (1988) estimates that this bias contributed $17 \mathrm{~m}$ at $50 \mathrm{hPa}$ and $71 \mathrm{~m}$ at $10 \mathrm{hPa}$ to the difference in geopotential height estimates from the two sondes. Statistical comparisons, however, show that the switch from VIZ to Vaisala RS80 at US stations introduced a shift of as much as $120 \mathrm{~m}$ at $50 \mathrm{hPa}$ in the daytime (Elliot et al., 2002). This may be in part due to pressure errors, which appear to have a much larger effect than temperature errors (e.g. Morris et al., 2012; Stauffer et al., 2014): comparisons with radar measurements of height showed the VIZ high relative to the radar (and the Vaisala) in daytime by $\sim 150 \mathrm{~m}$ at $20 \mathrm{hPa}$ and up to $500 \mathrm{~m}$ at $10 \mathrm{hPa}$ (Schmidlin, 1988; Nash and Schmidlin, 1987), while at night both VIZ and Vaisala RS80 calculated geopotentials were low by $\sim 100 \mathrm{~m}$ at $20 \mathrm{hPa}$ and $\sim 150 \mathrm{~m}$ at $10 \mathrm{hPa}$. The daytime differences correspond to ozone differences of $\sim 2$ and $\sim 7 \%$ at 20 and $10 \mathrm{hPa}$ respectively. The effect of pressure errors is most significant at higher altitudes: a $1 \mathrm{hPa}$ offset will introduce a geopotential height error of $63 \mathrm{~m}$ at $100 \mathrm{hPa}$, $120 \mathrm{~m}$ at $50 \mathrm{hPa}$, and over $300 \mathrm{~m}$ at $20 \mathrm{hPa}$; these correspond to ozone differences of $0.25,0.5$, and $\sim 4 \%$ respectively. Pressure errors also seem more variable: local noon flights during the same intercomparison show much smaller height differences between the VIZ and Vaisala.

The Vaisala RS-92 has replaced the RS-80 and has been in use in Canada since 2006. Comparison flights with GPS tracking show that it gives more accurate heights than the RS80; differences from the GPS are small (Steinbrecht et al., 2008; Nash et al., 2006). RS80 sondes, however, were found to be low by $\sim 20 \mathrm{~m}$ in the troposphere and high by $100 \mathrm{~m}$ at $10 \mathrm{hPa}$ (Steinbrecht et al., 2008; also da Silveira et al., 2006).

Unfortunately, intercomparison experiments do not tell the whole story, as not all manufacturing changes are advertised by a change in model number. For example, Steinbrecht et al. (2008) note systematic differences between batches of RS-92 sondes produced before July 2004. Overall, the expected systematic differences in the ozone profile resulting from radiosonde errors are probably small below $50 \mathrm{hPa}$. We do not attempt to correct for radiosonde errors but do include possible pressure offsets as an error source in the uncertainty estimation (Sect. 4). Estimated radiosonde errors are largest for the older VIZ sonde, with the manufacturer quoting a $1 \sigma$ uncertainty in the pressure measurement of $1 \mathrm{hPa}$.

\section{Effects of the corrections}

An analysis of the effects of these corrections is shown in Figs. 1-4 for the station at Edmonton (Stony Plain). The average change to the ozone profile has been calculated for the corrections described above, both individually and collectively. Figure 1 shows the changes for the 1970s when only Brewer-Mast sondes were flown at Edmonton. The largest change is in the lowermost troposphere, where the response correction raises ozone values by about $15 \%$, although the changes to the normalization make a significant difference as well. Note that in each case the profile, after one or more corrections are applied, is normalized, so that the corrected curves all include the effects of renormalization. This also has the effect of redistributing the correction over the profile. For example, the "Mateer" correction, which is about $10 \%$ at the top of Fig. 1, but 0 below $150 \mathrm{hPa}$, because of this redistribution introduces an additional negative change of about $1 \%$ in the tropospheric part of the corrected profile, over that introduced by the renormalization alone.

In Fig. 2, the changes to the ECC record in the 1980s are comparatively minor, although again the largest change is in the lowermost troposphere, where the solution volume correction raises ozone values by as much as $4 \%$. The new normalization also increases ozone values through the entire profile by $\sim 1 \%$. In the 1990s (Fig. 3) the shifts are larger: up to $2-3 \%$ throughout the stratosphere. Most of this appears to be due to the change of temperature measurement, from the rod thermistor at the base of the electronics unit, to the "box" temperature, and in a few cases in 1999, pump temperature measurements. In the 2000s (Fig. 4) the "Deshler" correction for the change to ENSCI sondes seems to almost cancel that 


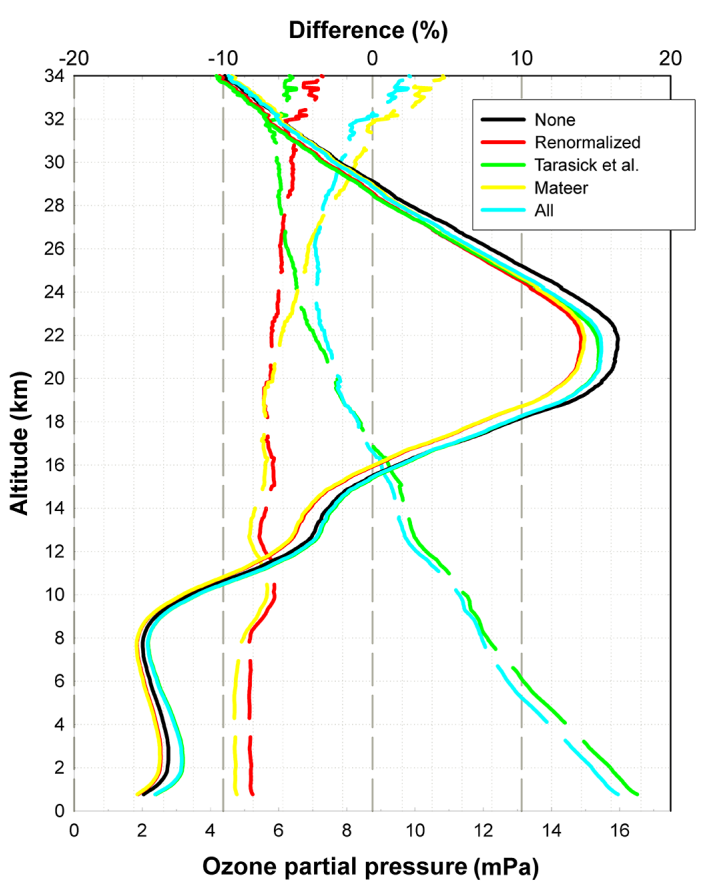

Edmonton: reprocessed 1972-1978

Figure 1. Average ozone profile at Edmonton before ("None") and after corrections to the Brewer-Mast record. Dashed lines show differences from "None" in percent. "Renormalized" shows the average change introduced by the use of the McPeters and Labow (2012) climatology (see Sect. 2.1); "Tarasick et al." shows that from the response correction (Sect. 2.2); "Mateer" shows the change caused by the switch to WMO-recommended pump corrections (Sect. 2.3). Note that in each case the profile is normalized, so that the curves Tarasick et al. and Mateer both include the effects of renormalization. The largest change is in the lowermost troposphere, where the response correction (Tarasick et al.) raises ozone values by about $15 \%$.

for the change of temperature measurement, so that the overall correction is close to 0 , except at the top of the profile and in the lower troposphere.

With the exception of the Brewer-Mast data in the troposphere, the overall effect of the corrections is generally modest. They can be summarized as

- tropospheric changes: increases of up to $5 \%$ after 1979 and up to $20 \%$ before 1980 (Brewer-Mast sondes), declining with altitude;

- stratospheric changes: decreases of up to $4 \%$ before 1980 at $25 \mathrm{~km}$, with smaller decreases above and below, increases of $\sim 1 \%$ in the 1980 s and $\sim 2-3 \%$ in the 1990 s, and little change in the 2000s.

An examination of the revised record shows that the removal of these artifacts from it has indeed reduced uncertainty, as measured by the changes in the comparison to the total ozone record. Table 3 describes these differences. The

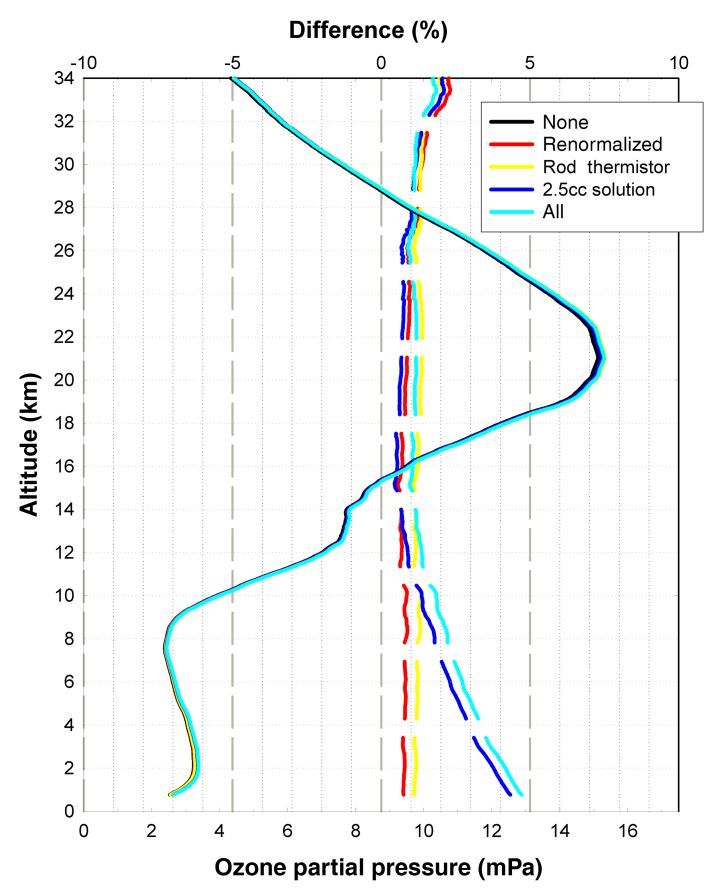

Edmonton: reprocessed 1980-1989

Figure 2. As Fig. 1 but for the first decade of ECC soundings. Dashed lines show differences from "None" in percent. "Rod thermistor" shows the average change introduced by the correction to the temperature measured by the rod thermistor (Sect. 2.6), and "2.5cc solution" that for the solution volume correction (Sect. 2.4). Note that each curve also includes the effects of renormalization. The changes to the ECC record in the 1980s are comparatively minor.

normalization factors are closer to 1 , and their variance is reduced, for both Brewer-Mast and ECC sondes. A trend in the normalization factors for the Brewer-Mast sondes is reduced, and that for ECC sondes (cf. Tarasick et al., 2005) is effectively removed (no longer statistically significant).

\section{Uncertainty analysis}

An important goal of the Ozonesonde Data Quality Assessment (O3S-DQA) is to produce an uncertainty analysis for ozonesonde data. There have been only a few published efforts to quantify the uncertainty in ozonesonde profile measurements, either from an analysis of error sources (Komhyr et al., 1995) or empirically from field or laboratory intercomparisons (Smit et al., 2007; Kerr et al., 1994; Deshler et al., 2008a; Barnes et al., 1985; Smit and ASOPOS panel, 2011) or via statistical data analysis (Liu et al., 2009). Here we attempt a "bottom-up" approach similar to that of Komhyr et al. (1995).

Table 4 lists the error sources considered in this analysis. The first five lines refer to errors that are assumed constant throughout the profile. 
Table 3. Cumulative effects of corrections to ozonesonde data for the record at Edmonton (Stony Plain), as indicated by changes in the comparison of the integrated profile to a coincident spectrophotometric total ozone measurement.

\begin{tabular}{|c|c|c|c|}
\hline & Mean ratio (normalization factor) & Standard deviation & Trend in normalization factors \\
\hline \multicolumn{4}{|c|}{ BM data (up to 1979) } \\
\hline Original & 1.27 & 0.303 & $5.5 \%$ decade $^{-1}$ \\
\hline Renormalized & 1.20 & 0.284 & \\
\hline All corrections & 1.03 & 0.257 & $4.5 \%$ decade $^{-1}$ \\
\hline \multicolumn{4}{|c|}{ ECC data (1980-2013) } \\
\hline Original & 0.97 & 0.110 & $-2.6 \pm 0.7 \%$ decade $^{-1}$ \\
\hline All corrections & 0.99 & 0.099 & $0.7 \pm 0.6 \%$ decade $^{-1}$ \\
\hline
\end{tabular}

Table 4. Sources of ozonesonde profile error considered in this analysis and their estimated magnitudes. See text for details.

\begin{tabular}{|c|c|c|c|c|c|}
\hline \multirow[t]{2}{*}{ Error source } & \multicolumn{5}{|c|}{ Uncertainty $(1 \sigma)$} \\
\hline & $\mathrm{BM}$ & $3 \mathrm{~A}$ & $4 \mathrm{~A}$ & $5 \mathrm{~A} / 6 \mathrm{~A}$ & $2 Z$ \\
\hline Stoichiometry & $\pm 1.0 \%$ & $\pm 1.0 \%$ & $\pm 1.0 \%$ & $\pm 1.0 \%$ & $\pm 1.0 \%$ \\
\hline$T$ measurement & $\pm 3.0 \%$ & $\pm 0.3 \%$ & $\pm 0.3 \%$ & $\pm 0.2 \%$ & $\pm 0.2 \%$ \\
\hline Pump calibration & $\pm 0.5 \%$ & $\pm 0.5 \%$ & $\pm 0.5 \%$ & $\pm 0.5 \%$ & $\pm 0.5 \%$ \\
\hline Pump cal. RH error & - & $\pm 0.5 \%$ & $\pm 0.5 \%$ & $\pm 0.5 \%$ & $\pm 0.5 \%$ \\
\hline ENSCI $1 \% \mathrm{KI}$ correction error & - & - & - & - & $\pm 0.5 \%$ \\
\hline Pump corr. error $(100 / 10 \mathrm{hPa})$ & $\pm 2.0 \% / \pm 6.9 \%$ & $\pm 0.5 \% / \pm 2.1 \%$ & $\pm 1.1 \% / \pm 2.6 \%$ & $\pm 1.1 \% / \pm 2.6 \%$ & $\pm 1.1 \% / \pm 2.6 \%$ \\
\hline $2.5 \mathrm{~mL}$ solution corr. error $(\propto p)$ & $\pm 4 \%(\mathrm{sl})$ & $\pm 4 \%(\mathrm{sl})$ & $\pm 4 \%(\mathrm{sl})$ & $\pm 4 \%(\mathrm{sl})$ & $\pm 4 \%(\mathrm{sl})$ \\
\hline Background current & $\pm 0.05 \mathrm{mPa}$ & $i_{\mathrm{B}}\left(1-p / p_{0}\right)$ & $i_{\mathrm{B}}\left(1-p / p_{0}\right)$ & $i_{\mathrm{B}}\left(1-p / p_{0}\right)$ & $i_{\mathrm{B}}\left(1-p / p_{0}\right)$ \\
\hline BM response corr. error ( $\propto$ correction) & $\pm 7.0 \%(\mathrm{sl})$ & - & - & - & - \\
\hline Iodine loss $(\propto 1 / p)$ & $\pm 6 \%(10 \mathrm{hPa})$ & - & - & - & - \\
\hline Ascent rate variation & - & $\pm 12 \% \cdot e^{-\Delta t / \tau} \nabla_{t} \mathrm{O}_{3}$ & $\pm 12 \% \cdot e^{-\Delta t / \tau} \nabla_{t} \mathrm{O}_{3}$ & $\pm 12 \% \cdot e^{-\Delta t / \tau} \nabla_{t} \mathrm{O}_{3}$ & $\pm 12 \% \cdot e^{-\Delta t / \tau} \nabla_{t} \mathrm{O}_{3}$ \\
\hline Pressure offset & $\pm 1 \mathrm{hPa}(\mathrm{VIZ})$ & $\pm 1 \mathrm{hPa}(\mathrm{VIZ})$ & $\pm 1 \mathrm{hPa}(\mathrm{VIZ})$ & $\pm 0.5 \mathrm{hPa}(\mathrm{RS} 80)$ & $\begin{array}{r} \pm 0.5 \mathrm{hPa}(\mathrm{RS} 80) \\
\pm 0.15 \mathrm{hPa}(\mathrm{RS} 92)\end{array}$ \\
\hline
\end{tabular}

\section{- Stoichiometry}

Although the stoichiometry of the neutral buffered-KI method for measuring ozone was the subject of some controversy in the 1970s (e.g. Boyd et al., 1970; Pitts et al., 1976), most workers have found a stoichiometry of 1.0 within experimental error (Hodgeson et al., 1971; Kopczynski and Bufalini, 1971; Dietz et al., 1973), especially when potassium bromide is added (Lanting, 1979; Bergshoeff et al., 1980), as is the case in ozonesondes, and provided that slow side reactions with the phosphate buffer are excluded (Saltzman and Gilbert, 1959; Flamm, 1977; Johnson et al., 2002). We have allowed a modest (1\%) uncertainty for the reaction stoichiometry in both types of ozonesonde.

- Temperature measurement

The Brewer-Mast sonde did not have a measurement of the instrument temperature, and so the processing assumes a constant temperature of $300 \mathrm{~K}$. Measurements of the actual temperature made by Dütsch (1966) and Steinbrecht et al. (1998) suggest that it varies over a range of 10-20 K (3-6\%) over a flight, with a standard deviation of $1-3 \%$. We have represented this as a $3 \%$ uncertainty. For the ECC sondes, the box temperature measurement in the $3 \mathrm{~A}$ and $4 \mathrm{~A}$ models was less accurate than the pump measurement used with later models; we have assumed a standard error of $0.5 \mathrm{~K}$ for the latter and $1.0 \mathrm{~K}$ for the former.

- Pump flow measurement

An examination of pre-flight volumetric pump flow measurement data from several sites shows that standard deviations of $0.1-0.3 \%$ in this measurement (performed the day before launch) are typical. However, differences between this measurement and the corresponding flow rate determination made at the manufacturer's facility are larger, with standard deviations of about $1 \%$. Torres (1981) found a $1 \sigma$ variation in the speed of individual model $3 \mathrm{~A}$ pump motors of $0.5 \%$. We have assumed a calibration uncertainty of $0.5 \%$ for all types of sonde.

- Relative humidity error

For ECC sondes an additional error source is present, as during the pump flow measurement the pump draws relatively dry air from the room and expels water-saturated air into the graduated cylinder. The measured volume is larger than the actual volume pumped by an amount pro- 


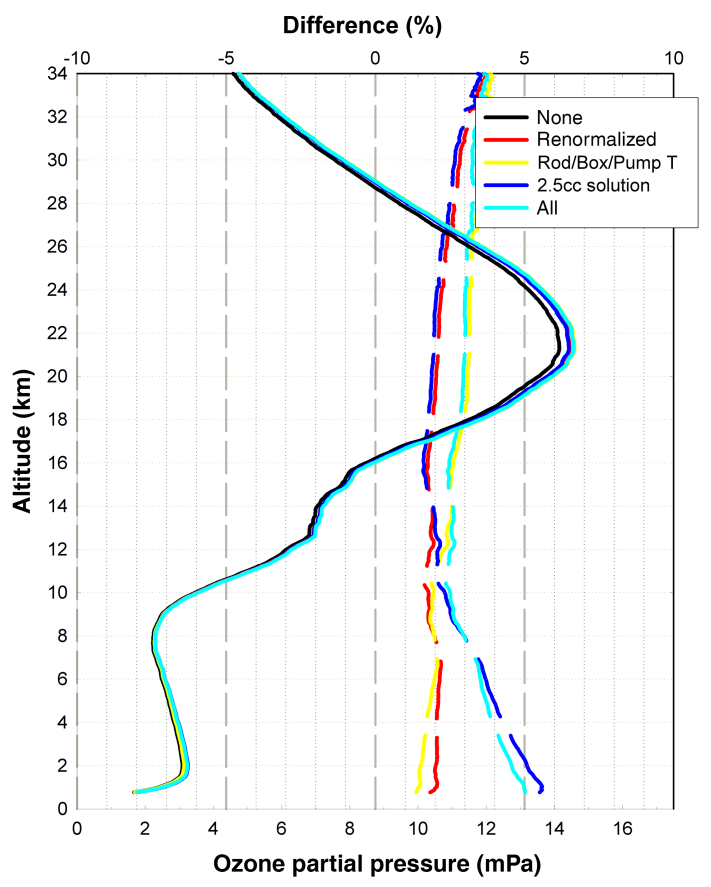

Edmonton: reprocessed 1990-1999

Figure 3. As Fig. 1 but for the 1990s. "Rod/Box/Pump T" shows the average change introduced by the corrections to the temperature measured by the different thermistors used during this decade (Sect. 2.6).

portional to the ratio of the saturation vapour pressure to the room pressure times the relative humidity change. Assuming a typical indoor humidity range of 40-70\% $(1 \sigma)$ gives an uncertainty of $\pm 0.5 \%$.

- Correction for use of standard $1 \%$ buffered-KI solution in ENSCI sondes

A bias correction of about $4 \%$ below $50 \mathrm{hPa}$ and somewhat larger above has been made to ENSCI sondes flown with $1 \%$ KI solution (Deshler et al., 2008b). We have allowed an additional uncertainty of $\pm 0.5 \%$, representing the standard error of the Deshler et al. (2008b) measurements, where this correction was made.

The latter seven lines in Table 4 refer to errors that vary throughout the profile, either with pressure or ozone gradient. Errors are calculated for each point in the profile:

\section{- Pump correction error}

Pump corrections, and their associated uncertainties, have been measured by a small number of authors. For Brewer-Mast sondes we have used the estimates of Komhyr and Harris (1965), and for ECC 3A sondes those of Torres (1981). For ECC 4A and later models (which have similar pumps), Johnson et al. (2002) provide a table summarizing the results of very large

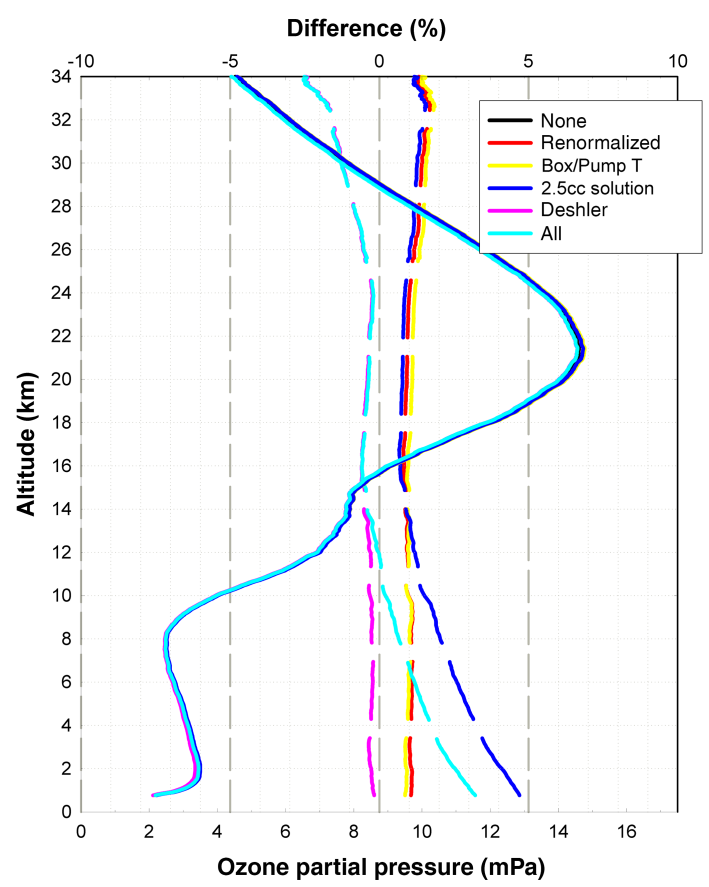

Edmonton: reprocessed 2000-2009

Figure 4. As Fig. 1 but for the 2000s. "Deshler" shows the average change introduced by the correction for the use of standard $1 \% \mathrm{KI}$ solution in ENSCI sondes (Sect. 2.5). Overall changes to the record are minor.

number of pump tests, primarily at the University of Wyoming and at the NOAA/CMDL laboratories. Both of these give much larger uncertainties than those quoted by Komhyr (1986), for a small number of tests. We have averaged these larger uncertainty values from the Wyoming and NOAA/CMDL tests. Torres (1981) also notes that his uncertainty estimates are based on a modest number of sondes from the same manufacturing batch and so may also be biased low. For each sonde type we have interpolated the measured uncertainties to other pressures to estimate this error for all points in each profile.

- Solution volume correction

As the ozone loss in sensors charged with only $2.5 \mathrm{~mL}$ of KI solution appears quite variable, a fairly large error of $4 \%$ at $1000 \mathrm{hPa}$, proportional to pressure, was assumed.

\section{- Background current}

As noted above, Canadian practice has been to treat background current as proportional to pressure, but it is now recommended (Smit and ASOPOS panel, 2011) to treat it as constant. Here we have treated the difference between the two values as an uncertainty, although it should be noted that although randomly variable in 
magnitude, it is always a positive bias. It is largest in relative terms just below the tropopause, where absolute amounts of ozone tend to be lowest. The average magnitude of the difference is largest in the 1980s and has a modest effect on calculated trends in the upper troposphere (Tarasick et al., 2005).

\section{- Brewer-Mast response correction}

The quadratic fit to the data shown in Fig. 7 of Tarasick et al. (2002) has a standard deviation of $\sim 7 \%$. We have added this uncertainty, scaled to the absolute magnitude of the correction, which is largest at $1000 \mathrm{hPa}$. The correction is largest (i.e. $7 \%$ ) at $1000 \mathrm{hPa}$ and declines quadratically with $\log$ (pressure).

- Iodine loss

Brewer-Mast sondes show increasing errors at higher altitudes relative to ECC sondes (Kerr et al., 1994; Fioletov et al., 2006). One possibility for this is solution evaporation and/or iodine loss from the sensing solution. The Brewer-Mast sensor has a somewhat more open construction that may allow more solution evaporation. Brewer-Mast sondes also use a much weaker $(0.1 \%)$ KI solution, which may allow significant iodine evaporation (Brewer and Milford, 1960; Tarasick et al., 2002). We have included an empirical estimate for this uncertainty of $0.6 / p$, where $p$ is pressure in $\mathrm{hPa}$.

\section{- Ascent rate variation}

The relatively slow response of ECC sondes causes their response to lag changes in the ozone concentration as the balloon rises. This implies that different balloon rise rates will give somewhat differing ozone amounts, especially in parts of the profile with large ozone gradients. We assumed an $e^{-1}$ response time of $\tau=20 \mathrm{~s}$ (Smit and Kley, 1998), so this difference is proportional to $e^{-\Delta t / \tau} \nabla_{t} \mathrm{O}_{3}$, where $\Delta t$ is the time interval between successive measurements, and $\nabla_{t} \mathrm{O}_{3}$ is, in essence, the vertical gradient of ozone but calculated as the difference in ozone between successive measurements as the balloon rises. The standard deviation of balloon rise rate at Edmonton in the 2000s is $\sim 12 \%$, which yields modest errors $(<1 \%)$ at the sharp ozone gradients near the tropopause and mostly insignificant errors elsewhere.

\section{- Pressure offset}

The error in ozone implied by a pressure offset equal to the manufacturer's estimated $1 \sigma$ uncertainty is calculated for every point in the profile by multiplying by the measured ozone gradient with respect to pressure. We have used the values quoted by Richner and Phillips (1981) for the VIZ sonde and Steinbrecht et al. (2008) for the Vaisala sondes.

The uncertainty profile is calculated for each flight, using the pressure and ozone partial pressure data for that

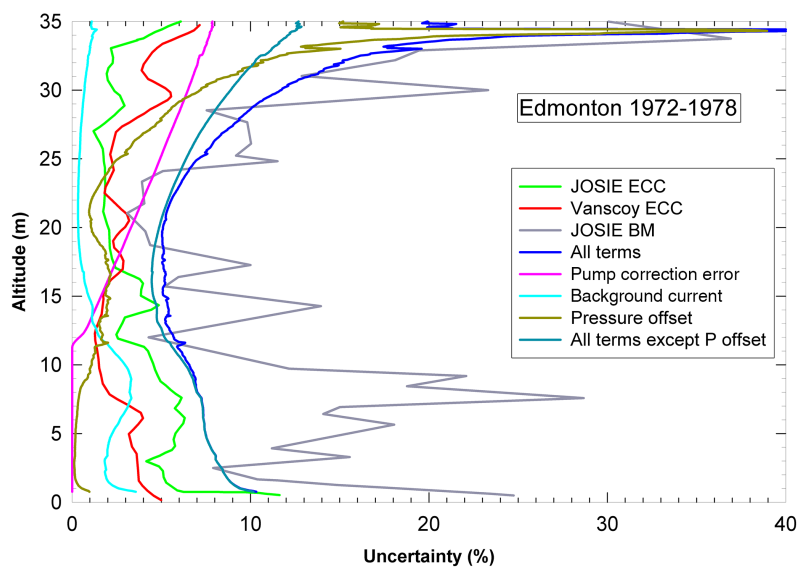

Figure 5. Average estimated uncertainty of Brewer-Mast soundings at Edmonton, showing contributions from selected sources. The total uncertainty without the contribution from radiosonde pressure offsets is also shown, to facilitate comparison with the JOSIE and Vanscoy intercomparison uncertainty estimates, which were referenced to a common pressure measurement. The uncertainty in the VIZ radiosonde pressure measurement dominates the calculated uncertainty above about $32 \mathrm{~km}$.

flight. Figure 5 shows the average uncertainty profile for the Brewer-Mast flights at Edmonton, along with the standard deviation of the response of ECC sondes during the Vanscoy and JOSIE 1996 ozonesonde intercomparison campaigns (Kerr et al., 1994; Smit et al., 2007) and the standard deviation of the response of Brewer-Mast sondes during the Vanscoy campaign (Kerr et al., 1994). Several of the individual contributions to the overall uncertainty are shown. The total uncertainty without the contribution from radiosonde pressure offsets is also shown, to facilitate comparison with the JOSIE 1996 and Vanscoy intercomparison uncertainty estimates, which were referenced to a common pressure measurement. It will be noted that the uncertainty in the VIZ radiosonde pressure measurement dominates the calculated uncertainty above about $32 \mathrm{~km}$.

Figure 6 shows similar calculations for the first decade of ECC soundings ( $3 \mathrm{~A}$ and $4 \mathrm{~A}$ models). The VIZ radiosonde was used throughout. As the other sources of uncertainty are smaller, the uncertainty in the VIZ radiosonde pressure measurement now dominates the calculated uncertainty above about $26 \mathrm{~km}$. Figures 7 and 8 show similar calculations for the 1990s and 2000s respectively. Notable improvements are reductions in background current and the reduction of pressure offsets with the introduction of the Vaisala radiosondes.

\section{Time series and trend analysis}

For this analysis each ozone profile was represented by a surface-level measurement (the ozone measurement at sonde release) and 11 layers equally spaced in log pressure (each 


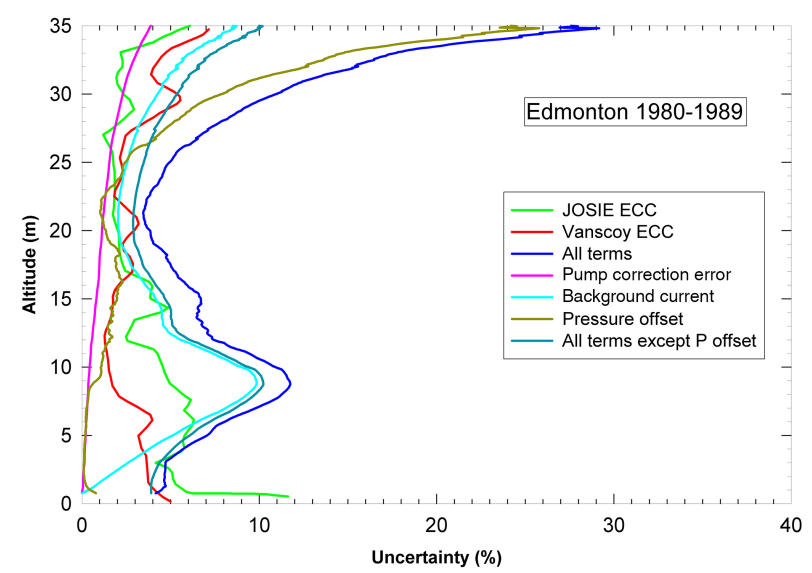

Figure 6. Average estimated uncertainty of ECC (3A and 4A) soundings in the 1980s at Edmonton, showing contributions from selected sources. The total uncertainty without the contribution from radiosonde pressure offsets is also shown, to facilitate comparison with the JOSIE and Vanscoy intercomparison uncertainty estimates, which were referenced to a common pressure measurement. As the overall uncertainty is smaller, the uncertainty in the VIZ radiosonde pressure measurement now dominates the calculated uncertainty above about $26 \mathrm{~km}$.

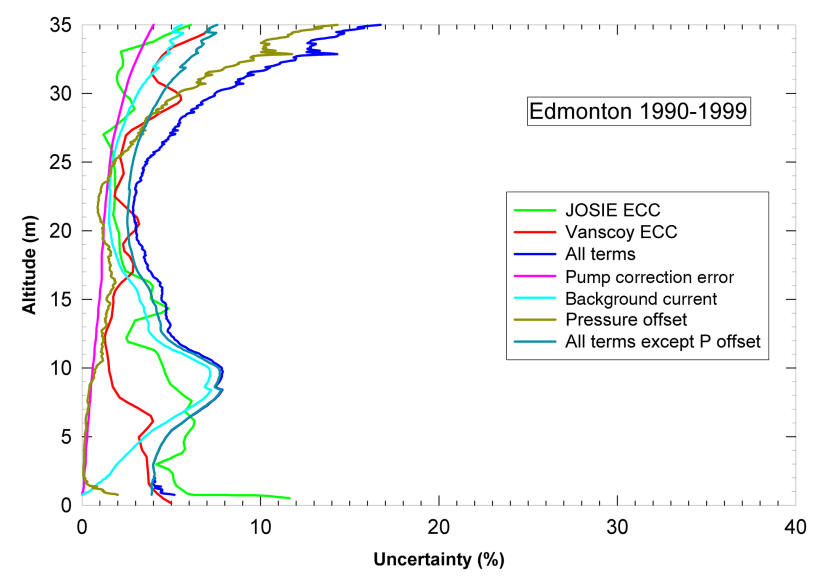

Figure 7. Average estimated uncertainty of ECC (4A and 5A) soundings in the 1990s at Edmonton, showing contributions from selected sources. The uncertainty in the VIZ or (from 1994) RS-80 radiosonde pressure measurement dominates the calculated uncertainty above about $28 \mathrm{~km}$.

$\sim 3 \mathrm{~km}$ in thickness). Troposphere and stratosphere have been explicitly separated: that is, integration for the 400 $250 \mathrm{hPa}$ layer is from 400 to $250 \mathrm{hPa}$ or the tropopause, whichever comes first. Similarly, integration of the 250 $158 \mathrm{hPa}$ layer starts either at $250 \mathrm{hPa}$ or at the tropopause, if the latter is found above $250 \mathrm{hPa}$. (Cases where the tropopause is below the $400 \mathrm{hPa}$ height or above $158 \mathrm{hPa}$ occur rarely but are dealt with similarly.) The WMO definition of the tropopause (WMO, 1992) is employed.

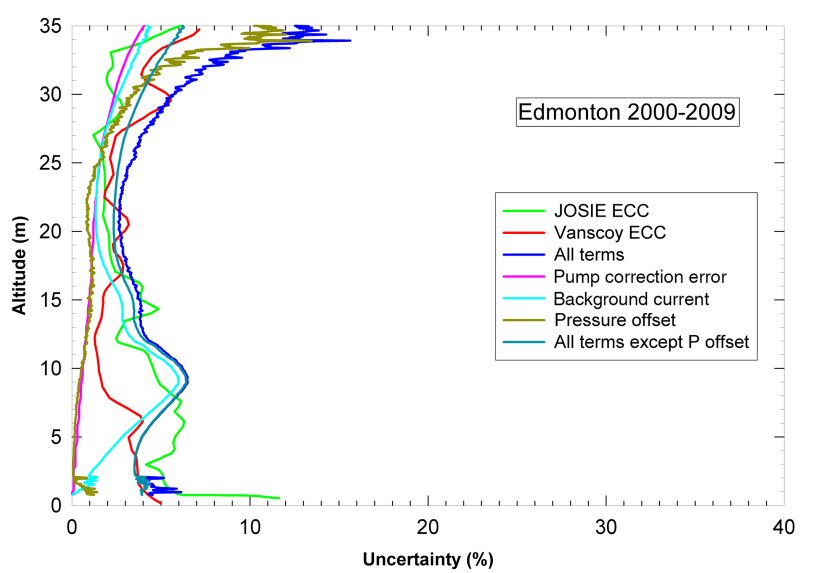

Figure 8. Average estimated uncertainty of ECC (5A and ENSCI) soundings in the 2000s at Edmonton, showing contributions from selected sources. The uncertainty in the RS- 80 or (from 2006) RS92 radiosonde pressure measurement now dominates the calculated uncertainty only above about $31 \mathrm{~km}$.

Partial ozone columns were integrated within these 11 layers and divided by the pressure difference across each layer to find average ozone mixing ratios. These and the ground-level mixing ratio values were deseasonalized by subtracting the average annual cycle as described in Tarasick et al. (1995). The deseasonalized time series were also adjusted for the effects of diurnal variation in ozone concentration. Sondes are generally launched at either 12:00 or 00:00 GMT, which are early morning and mid-afternoon in Kelowna and Edmonton, and later at other stations. The amount of diurnal shift (a scalar value for each station at each level) was calculated as the average difference between values for the two launch times, where both were available in the same year and month. The difference presumably results from the competing effects of photochemical production and NO titration, which vary with time of day, but the sparse (weekly) data make it difficult to draw firm conclusions. The effect is significant primarily at Edmonton, where it can be as large as $42 \%$ at ground level and $14 \%$ below $700 \mathrm{hPa}$ (Tarasick et al., 2005). However, for consistency all stations were adjusted at all levels.

Figures 9 through 14 show time series of percent deviations from the long-term mean in monthly average ozone mixing ratio for three northern midlatitude stations (Edmonton, Goose Bay, and Churchill) and for the three Arctic stations (Resolute, Alert, and Eureka). For ease of visualization, a 4-month running average has been applied to smooth the data.

Figures 9 and 10 show the surface and the three tropospheric layers. The most notable feature in both cases is that there appears to be no long-term trend in the troposphere, over the 45-year (midlatitude) or 48-year (Arctic) record, except at the surface and possibly in the upper troposphere of the Arctic. In the latter cases these trends are negative. 


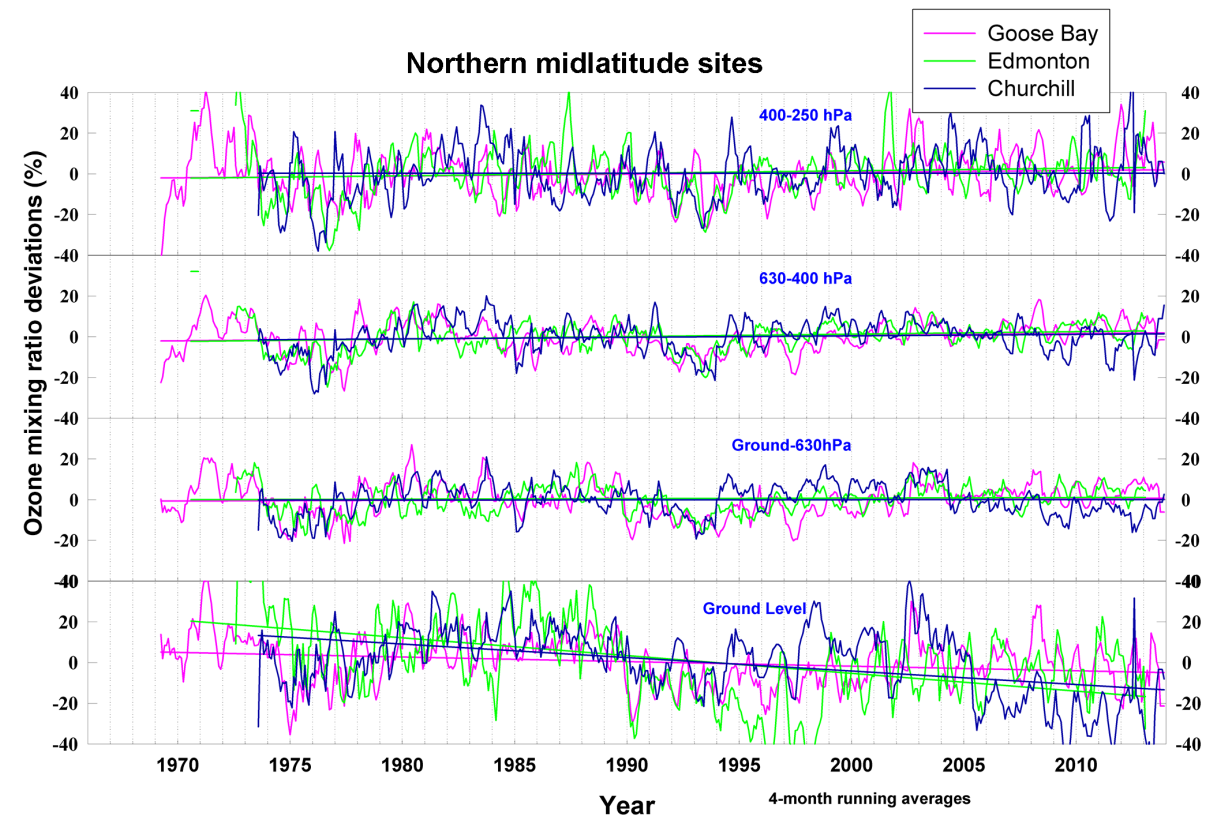

Figure 9. Percent deviations in average ozone mixing ratio for the surface and three tropospheric layers, for three midlatitude stations. Monthly anomalies have been smoothed with a 4-month running average. The overall station trend lines (up to 45 years in the case of Goose Bay) are shown. The troposphere and stratosphere have been explicitly separated; that is, integration for the $400-250 \mathrm{hPa}$ layer is from 400 to $250 \mathrm{hPa}$ or the tropopause, whichever comes first.

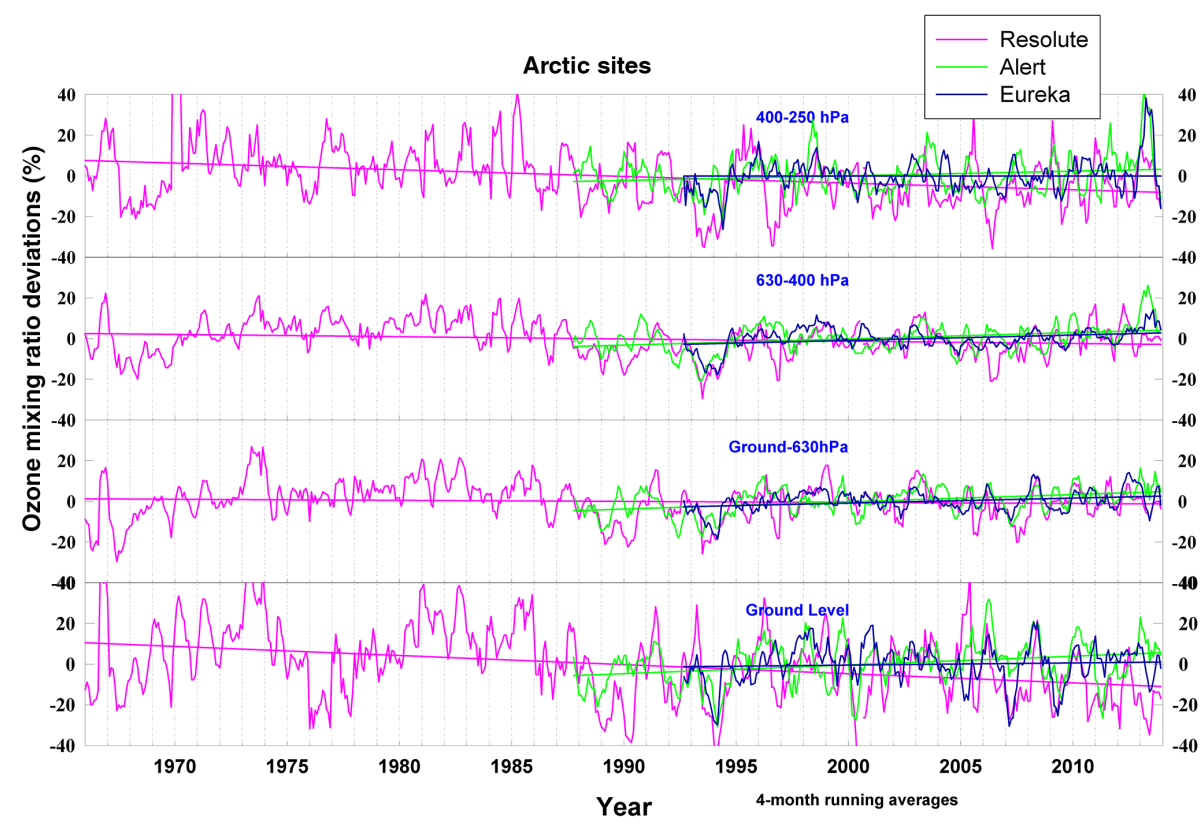

Figure 10. As Fig. 9, for the three Arctic stations. The overall station trend lines (up to 48 years in the case of Resolute) are shown.

The surface trend at the northern midlatitude sites may be primarily due to urban development near Edmonton (Tarasick et al., 2005), although Churchill shows a strong decline at the surface in recent decades, for unknown reasons. The surface trend at the Arctic sites may be related to an increase in the frequency of halogen-induced surface ozone depletions, which appear to correlate with negative anomalies in the surface ozone record shown in Fig. 10 (Oltmans et al., 2012). The frequency of such events at Resolute has increased by nearly $32 \%$ over the $1966-2013$ period (Tarasick et al., 2014). 


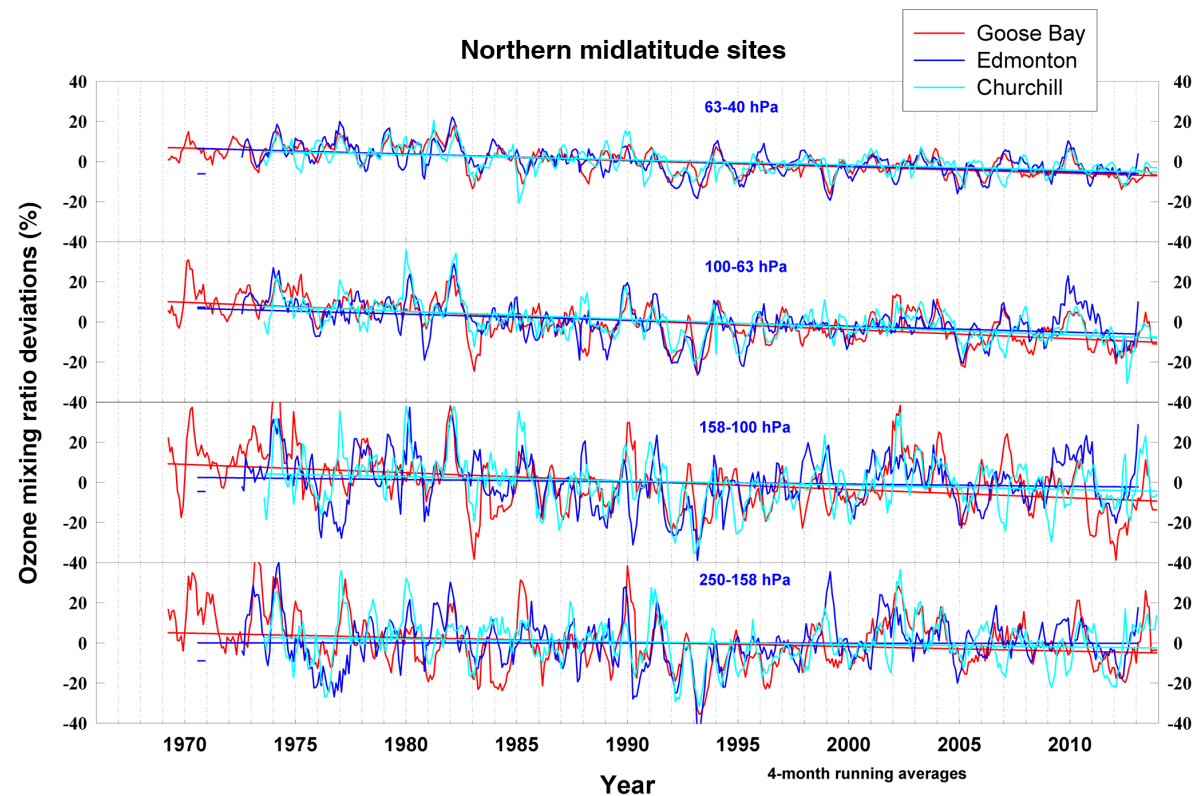

Figure 11. Percent deviations in average ozone mixing ratio for four lower stratospheric layers, using data from three midlatitude stations. Monthly anomalies have been smoothed with a 4-month running average. The overall station trend lines are shown. The troposphere and stratosphere have been explicitly separated; that is, integration of the $250-158 \mathrm{hPa}$ layer starts either at $250 \mathrm{hPa}$ or at the tropopause, when the latter is found above $250 \mathrm{hPa}$.

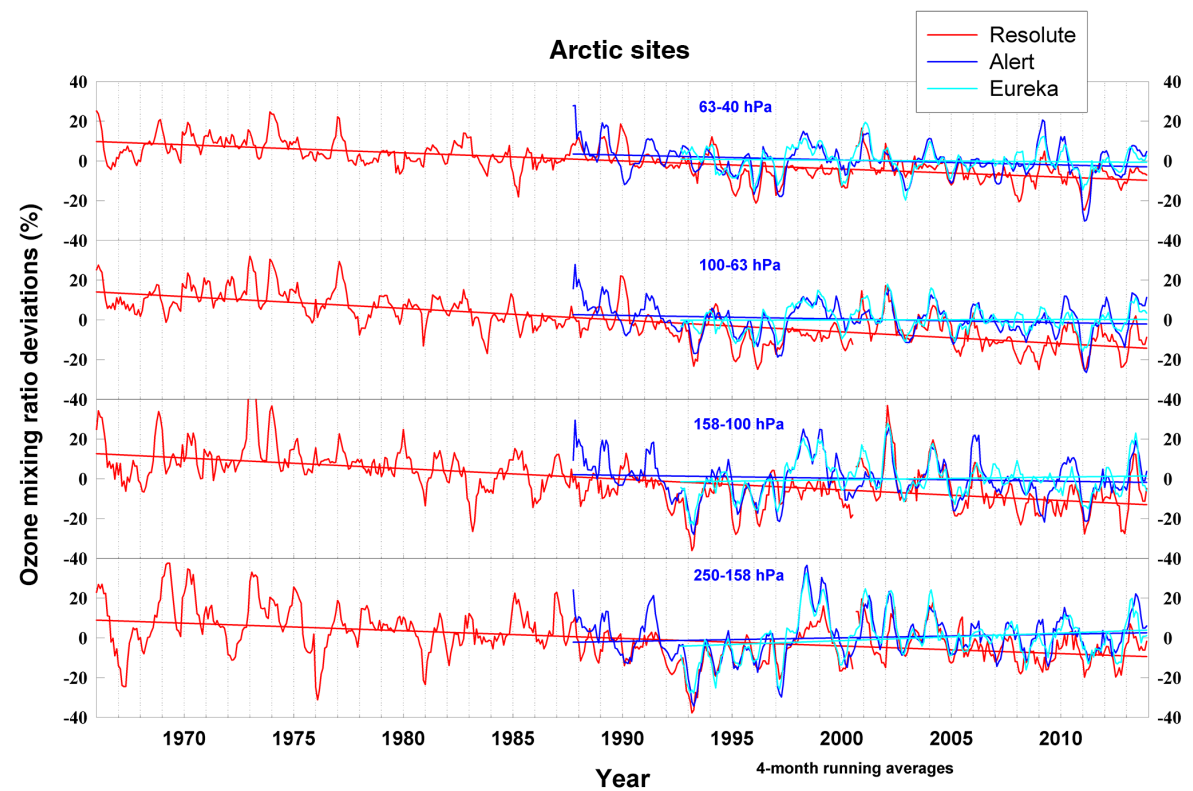

Figure 12. As Fig. 11, for the three Arctic stations. The overall station trend lines are shown.

The decadal trends (not shown) are much more variable. In general, however, trends are negative in the 1980s, positive in the 1990s, and small after 2000.

Figures 11 and 12 show the four lower stratospheric layers. Here the long-term trends are all negative (with the exception of Eureka, whose record began in 1993). Notable features are the low values in the early 1990s and the high values in the early 2000s, the latter possibly caused by small changes in the Brewer-Dobson circulation (Bönisch et al., 2011). These high values cause the lower stratospheric trends for 2000 2013 (which might otherwise be expected to show signs of recovery from stratospheric ozone depletion with declining effective chlorine levels over this period) to be negative, both at midlatitudes and in the Arctic. In the Arctic, particularly 


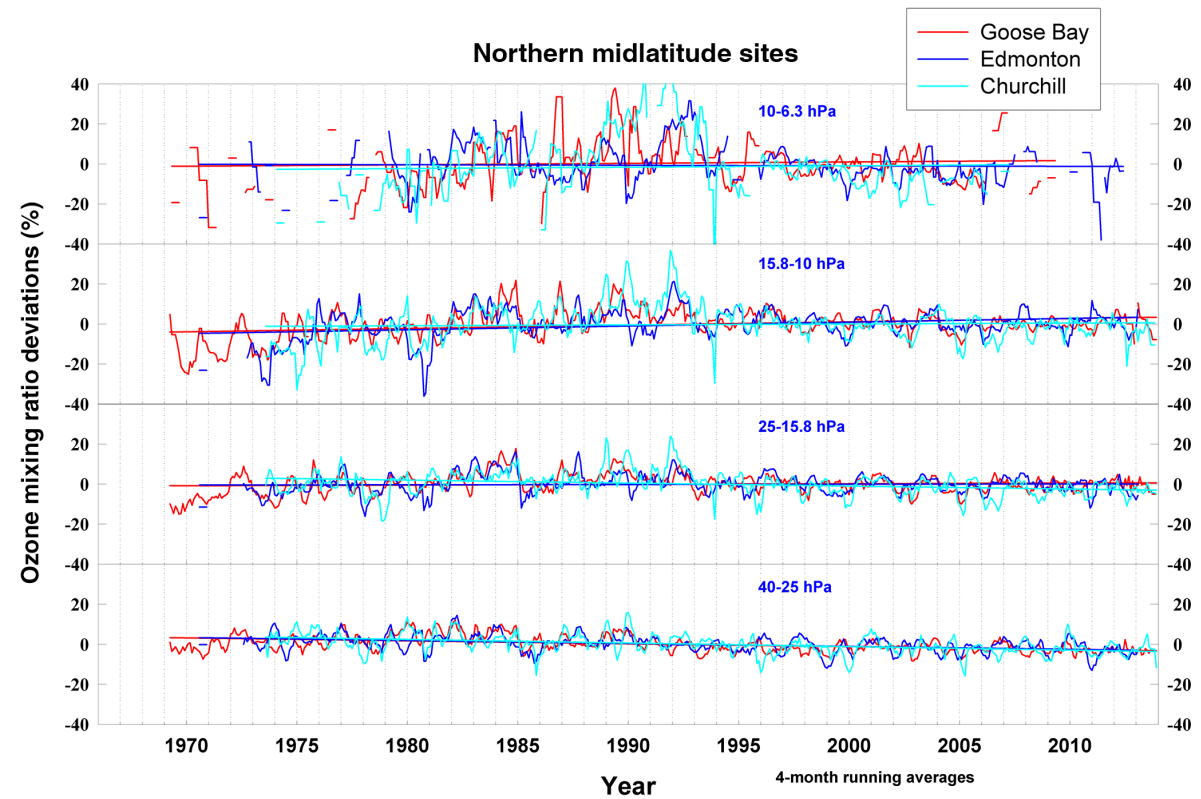

Figure 13. Percent deviations in average ozone mixing ratio for four middle stratospheric layers, using data from three midlatitude stations. Monthly anomalies have been smoothed with a 4-month running average. The overall station trend lines are shown.

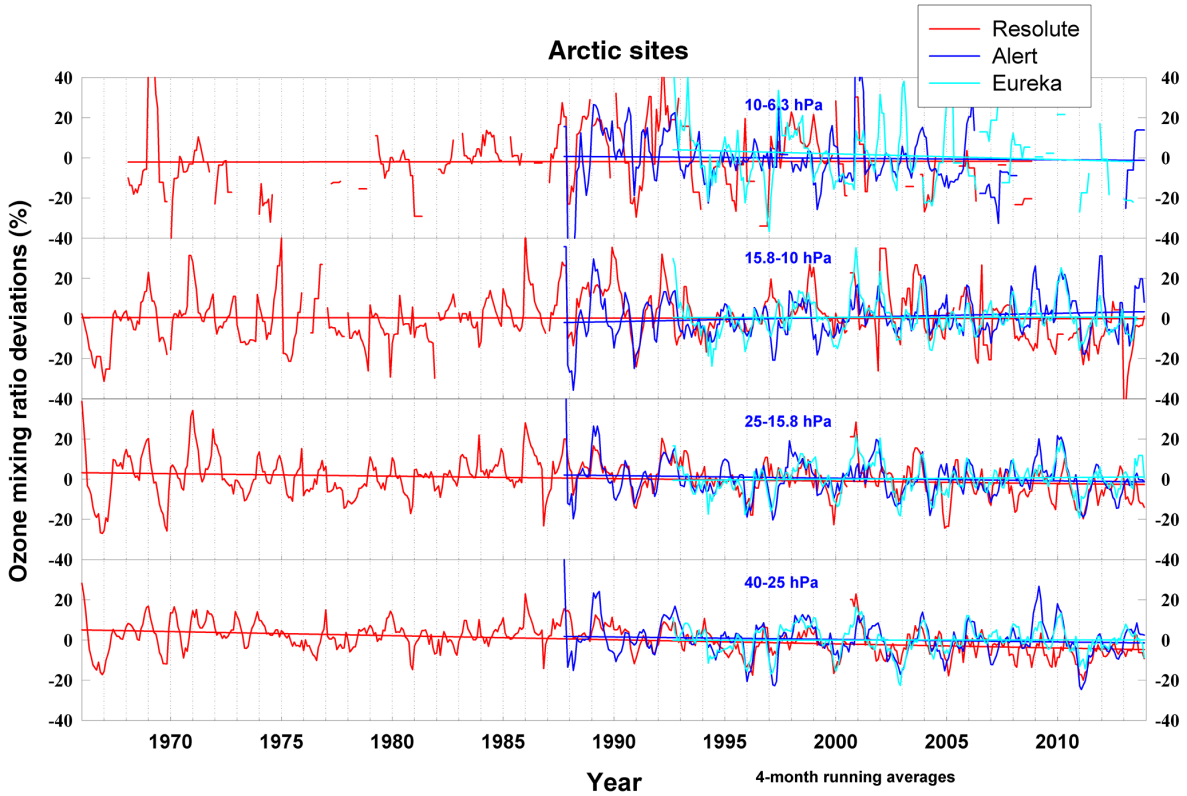

Figure 14. As Fig. 13, for the three Arctic stations. The overall station trend lines are shown.

above $100 \mathrm{hPa}$, the springtime negative anomalies in cold vortex years $(1996,1997,2000,2005$, and 2011) are evident. At these levels the 2011 anomaly (e.g. Manney et al., 2011) is larger than the 1993 anomaly related to the eruption of Mt. Pinatubo.

The four middle stratospheric layers (Figs. 13 and 14) show less variability, and the decadal trends more closely follow the long-term trends at each level. These long-term linear trends are shown in Figs. 15-17.
Figure 15 shows calculated trends in ozone mixing ratio from ozonesonde data at six Canadian stations from 1966 to 2013 (for Alert and Eureka from 1987 and 1992 respectively), for the ground level and the 11 layers equally spaced in $\log$ pressure. To calculate these trends the deseasonalized station time series were averaged by month, and a simple linear regression (without subtraction of QBO, solar-cycle, or other known influences on ozone) was used to derive trends. Trends are expressed as percent per decade, relative to the 


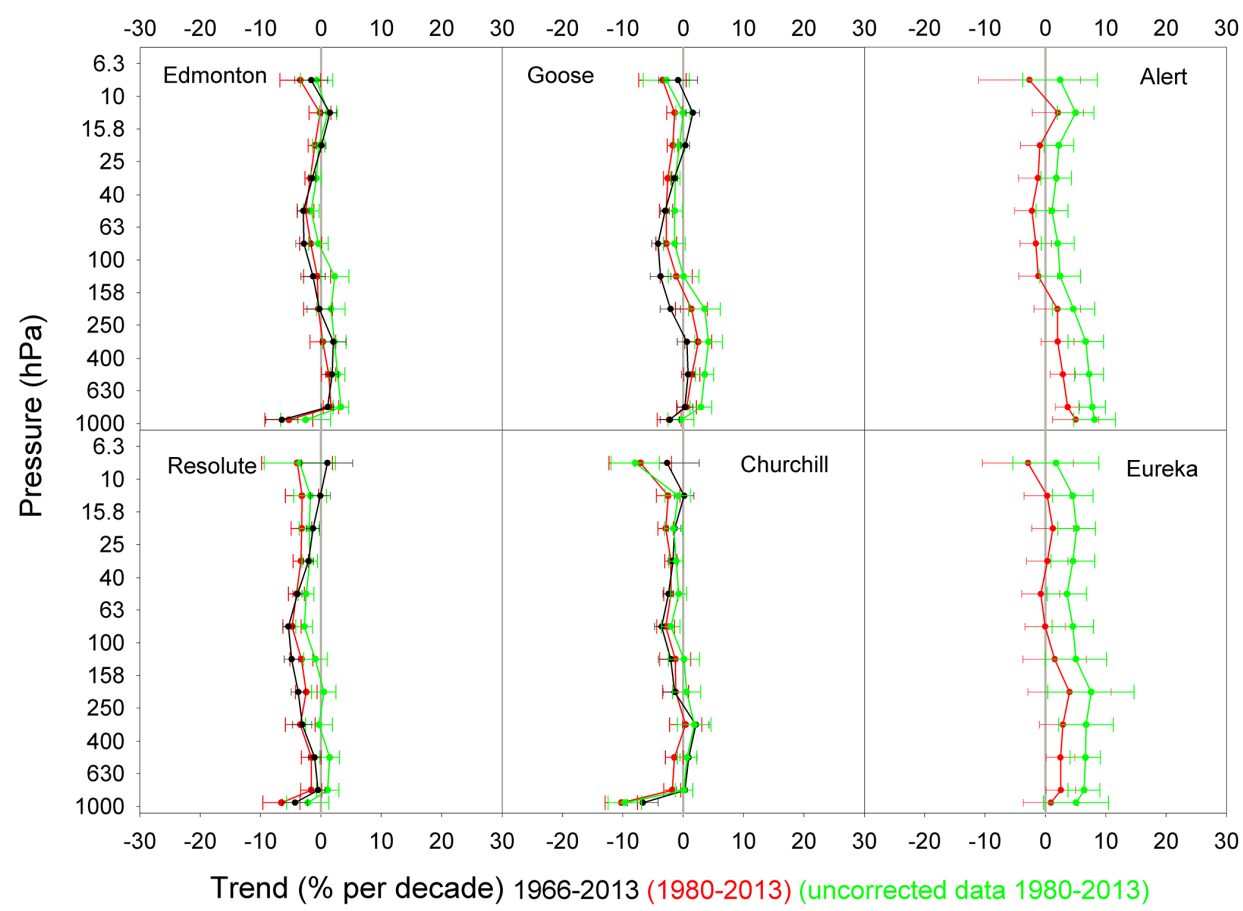

Figure 15. Linear trends in ozone mixing ratio for the overall (48-year) period at the six Canadian sites with long-term ozonesonde records, for the surface and 11 layers equally spaced in log pressure $(\sim 3 \mathrm{~km})$. Error bars show $95 \%(2 \sigma)$ confidence limits. The troposphere and stratosphere have been explicitly separated; that is, integration of the $250-158 \mathrm{hPa}$ layer starts either at $250 \mathrm{hPa}$ or at the tropopause, when the latter is found above $250 \mathrm{hPa}$. Similarly, integration of the $250-158 \mathrm{hPa}$ layer starts either at $250 \mathrm{hPa}$ or at the tropopause, when the latter is found above $250 \mathrm{hPa}$. Trends using only ECC data (from 1980) are shown in red. Trends from 1980 using ECC data before corrections are applied are shown in green.

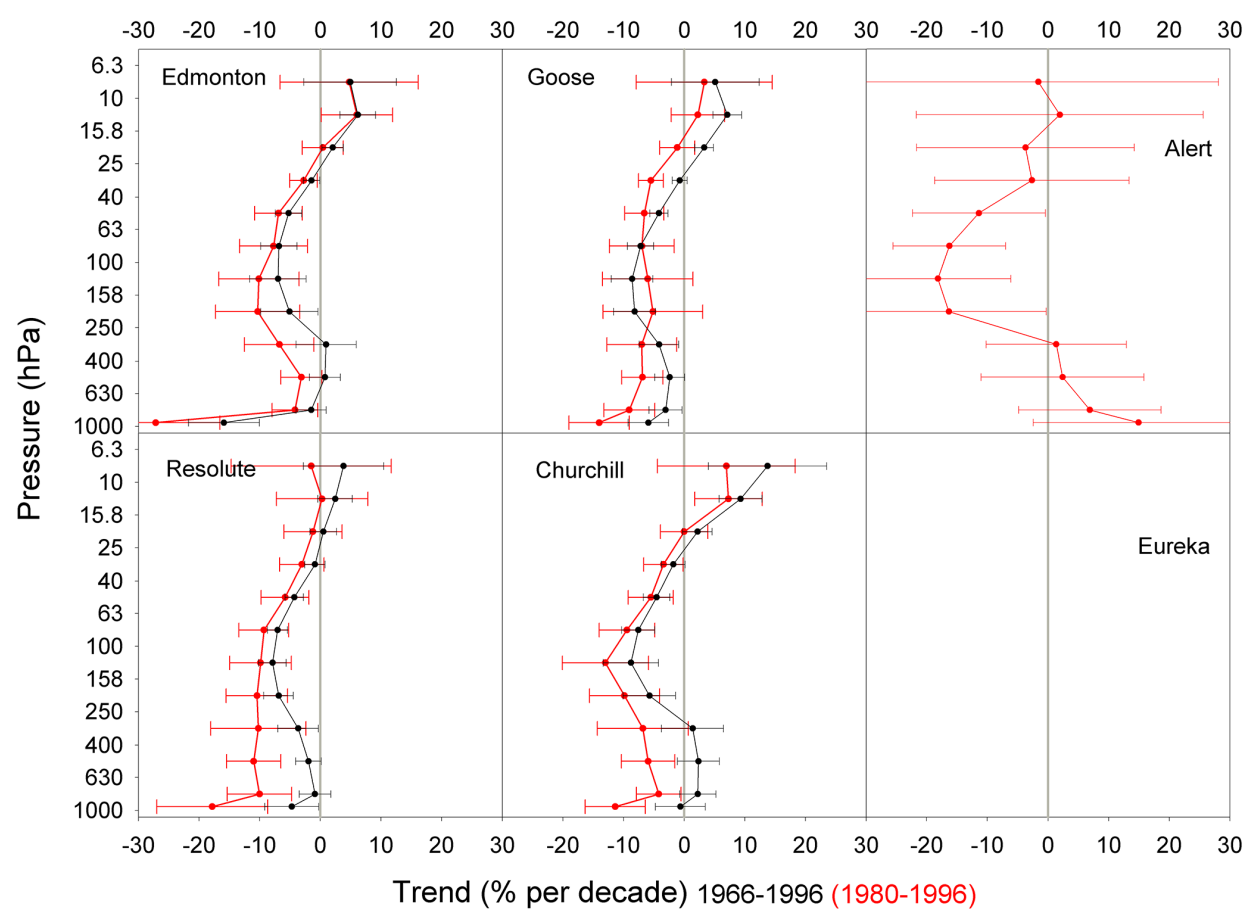

Figure 16. As Fig. 15 but for 1966-1996. Trends using only ECC data (from 1980) are shown in red. 


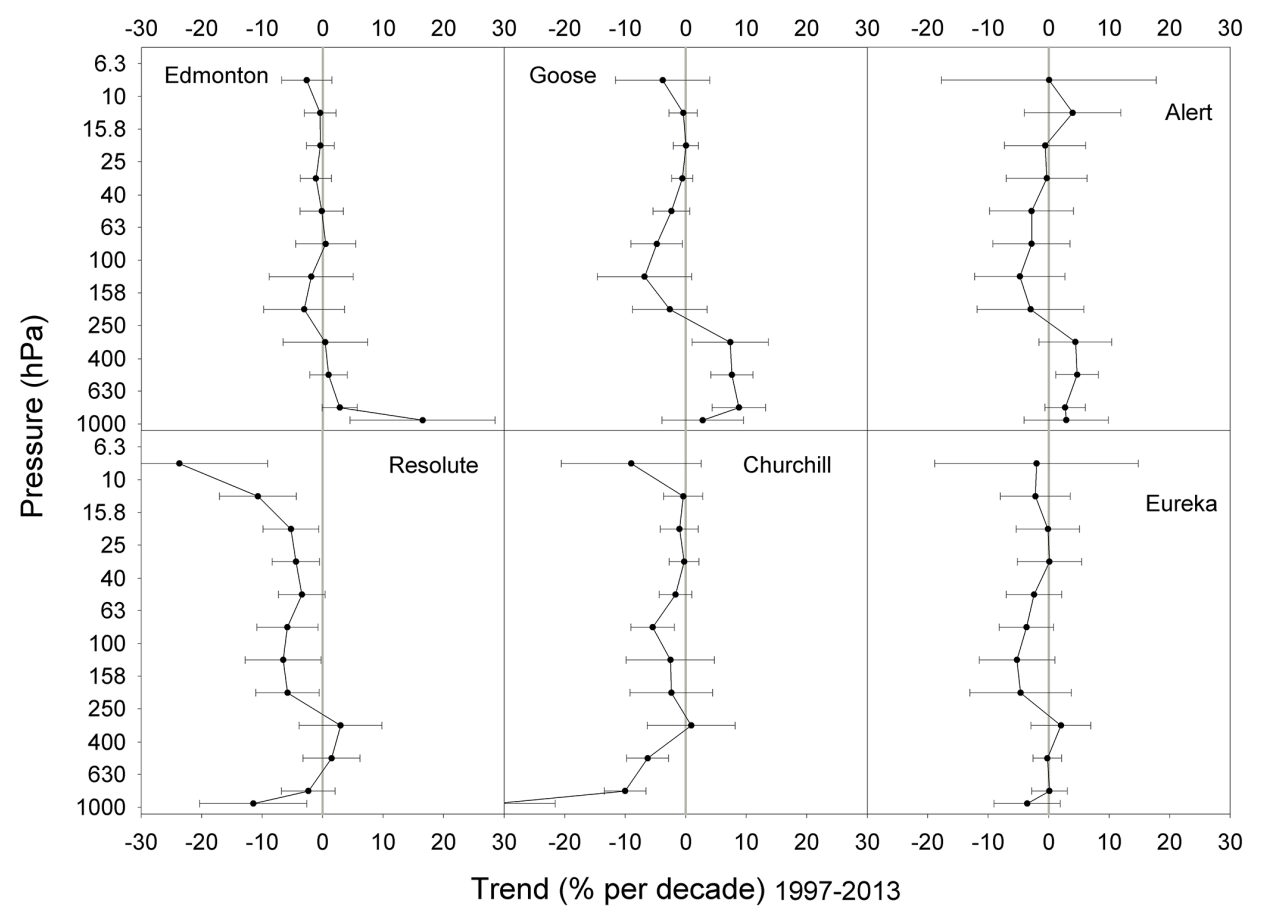

Figure 17. As Fig. 15 but for 1997-2013.

layer mean. The time series of monthly means show in general significant autocorrelation both in the stratosphere and the troposphere. Allowance is made for this in the confidence limits for trends by basing the confidence limit calculation on a (reduced) effective sample size, $n_{\mathrm{eff}}=n(1-\rho) /(1+\rho)$, where $\rho$ is the lag- 1 autocorrelation coefficient, and the ozone variability is assumed to be an $\mathrm{AR}(1)$ process (Zwiers and von Storch, 1995; Thiébaux and Zwiers, 1984).

Except at the surface, trends in the troposphere are in general non-significant over this very significant period. Trends in the middle stratosphere are also non-significant at the $95 \%$ $(2 \sigma)$ level, while those in the lower stratosphere are significant and negative. Trends in the lower stratosphere, however, are as large $-5 \%$ per decade over the 48 -year record. To gauge the uncertainty introduced by the addition of the older Brewer-Mast data, we have also calculated trends using only ECC data (that is, from 1980). The differences are surprisingly modest. We also show trends from 1980 calculated using ECC data before corrections are applied. The largest differences are seen at Alert and Eureka. The increases of 2$5 \%$ to the 1990s data (Fig. 3) have a larger effect on trends at these sites as they lack data from the early 1980s.

For comparison with other analyses in the $\mathrm{SI}^{2} \mathrm{~N}$ initiative (e.g. Harris et al., 2015) and the WMO Scientific Assessment of Ozone Depletion: 2014 (WMO, 2014), in Figs. 16 and 17 we show trends calculated using only data prior to 1997 (Fig. 16) and from 1997 to 2013 (Fig. 17). The trends for 1966-1996 show a similar picture to that of Fig. 15, although here some of the middle stratospheric layers show positive trends. When the trends are calculated using only data after 1979 (that is, ECC-only data) the trend picture is similar. However, trends in the 17-year period from 1997 to 2013 are almost all non-significant at the $95 \%(2 \sigma)$ level, except at the surface, which shows some surprisingly large variations. This is true even in the Arctic lower stratosphere, despite the large negative anomaly in 1997 (Fig. 14). Since stratospheric halogen loading has been decreasing during this period (WMO, 2014), the lack of evident ozone increases may be due to atmospheric variability (Kiesewetter et al., 2010; Chehade et al., 2014), in particular the high values in the early 2000s, possibly caused by changes in the BrewerDobson circulation (Bönisch et al., 2011). However, the standard deviations of the monthly ozone anomalies in the stratosphere at the four long-term stations for the 17 years prior to 1997 average 8-40\% greater than those for the 17-year period 1997-2013, which suggests that the stratosphere has in fact been less variable in the latter period.

\section{Conclusion}

As part of the SPARC/IO 3 C/IGACO-O3/NDACC $\left(\mathrm{SI}^{2} \mathrm{~N}\right)$ initiative, Canada's important record of ozone sounding data has been re-evaluated, taking into account the estimated effects of changes in the type and design of ozonesondes used in Canada over the last 5 decades.

The effect of the corrections is generally modest. However, the overall result is entirely positive: the comparison with co-located total ozone spectrometers is improved, in 
terms of both bias and standard deviation, and trends in the bias have been reduced or eliminated. An uncertainty analysis (including the additional uncertainty from the corrections, where appropriate) has also been conducted, and the altitudedependent estimated uncertainty is included with each revised profile.

The resulting time series show negative trends in the lower stratosphere of up to $5 \%$ per decade for the period 19662013. Most of this decline occurred before 1997, and linear trends for the more recent period are generally not significant. The time series also show large variations from year to year. Some of these anomalies can be related to cold winters (in the Arctic stratosphere) or changes in the Brewer-Dobson circulation, which may thereby be influencing trends.

In the troposphere trends for the 48-year period are small and for the most part not significant. This suggests that ozone levels in the free troposphere over Canada have not changed significantly in nearly 50 years.

Acknowledgements. The authors thank the many observers who, over many years, obtained the ozonesonde measurements used in this study. Their careful work is gratefully acknowledged. The ozone sounding data were obtained from the World Ozone and Ultraviolet Radiation Data Centre (WOUDC, http://www.woudc.org) operated by Environment Canada, Toronto, Ontario, Canada, under the auspices of the World Meteorological Organization.

Edited by: C. von Savigny

\section{References}

Attmannspacher, A. and Dütsch, H. U.: Second international ozone sonde intercomparison at the Observatory Hohenpeissenberg, Ber. Dtsch. Wetterdienstes, 157, 1-64, 1981.

Barnes, R. A., Bandy, A. R., and Torres, A. L.: Electrochemical concentration cell ozonesonde accuracy and precision, J. Geophys. Res., 90, 7881-7887, 1985.

Basher, R. E.: Review of the Dobson spectrophotometer and its accuracy, WMO Ozone Rep. 13, World Meteorol. Org., Geneva, 1982.

Beekmann, M., Ancellet, G., Mégie, G., Smit, H. G. J., and Kley, D.: Intercomparison campaign of vertical ozone profiles including electrochemical sondes of ECC and Brewer-Mast type and a ground-based UV-differential absorption lidar, J. Atmos. Chem., 19, 259-288, 1994.

Beekmann, M., Ancellet, G., Martin, D., Abonnel, C., Duverneuil, G., Eideliman, F., Bessemoulin, P., Fritz, N., and Girard, E.: Intercomparison of tropospheric ozone profiles obtained by electrochemical sondes, a ground-based lidar and an airborne UVphotometer, Atmos. Environ., 29, 1027-1042, 1995.

Bergshoeff, G., Lanting, R. W., Prop, J. M. G., and Reynders, H. F. R.: Improved neutral buffered potassium iodide method for ozone, Anal. Chem., 52, 541-546, 1980.

Bönisch, H., Engel, A., Birner, Th., Hoor, P., Tarasick, D. W., and Ray, E. A.: On the structural changes in the Brewer-Dobson circulation after 2000, Atmos. Chem. Phys., 11, 3937-3948, doi:10.5194/acp-11-3937-2011, 2011.

Bottenheim, J. W., Fuentes, J. D., Tarasick, D. W., and Anlauf, K. G.: Ozone in the Arctic lower troposphere during winter and spring 2000 (ALERT2000), Atmos. Environ., 36, 2535-2544, 2002.

Boyd, A. W., Willis, C., and Cyr, R.: New determination of stoichiometry of the iodometric method for ozone analysis at $\mathrm{pH} 7.0$, Anal. Chem., 42, 670-672, doi:10.1021/ac60288a030, 1970.

Boyd, I., Bodeker, G., Connor, B., Swart, D., and Brinksma, E.: An assessment of ECC ozone sondes operated using 1 and $0.5, \% \mathrm{KI}$ cathode solutions at Lauder, New Zealand, Geophys. Res. Lett., 25, 2409-2412, 1998.

Brewer, A. W. and Milford, J. R.: The Oxford-Kew ozone sonde, Proc. R. Soc. London, Ser. A, 256, 470-495, 1960.

Chehade, W., Weber, M., and Burrows, J. P.: Total ozone trends and variability during 1979-2012 from merged data sets of various satellites, Atmos. Chem. Phys., 14, 7059-7074, doi:10.5194/acp14-7059-2014, 2014.

Claude, H., Hartmannsgruber, R., and Köhler, U.: Measurement of Atmospheric Profiles using the Brewer-Mast Sonde, WMO Global Ozone Research and Monitoring Project, Report No. 17, 1987.

da Silveira, R. B., Fisch, G. F., Machado, L. A. T., Dall' Antonia Jr., A. M., Sapucci, L. F., Fernandes, D., Marques, R., and Nash, J.: WMO intercomparison of GPS radiosondes, Alcantara, Brazil, 20 May-10 June 2001. WMO/TD-No. 1314, 65 pp., available at: http://www.wmo.int/pages/prog/www/IMOP/publications/ IOM-90_RSO-Brazil/IOM-90_RSO_EMA_Alcantara2001.pdf, 2006.

Davies, J., McElroy, C. T., Tarasick, D. W., and Wardle, D. I.: Ozone Capture Efficiency in ECC Ozonesondes; Measurements made in the Laboratory and during Balloon Flights, EAE03-A-13703, Geophysical Research Abstracts, Vol. 5, 13703, EGS-AGU-EUG Joint Assembly, Nice, France, 6-11 April 2003.

Deshler, T., Mercer, J., Smit, H. G. J., Stuebi, R., Levrat, G., Johnson, B. J., Oltmans, S. J., Kivi, R., Thompson, A. M., Witte, J., Davies, J., Schmidlin, F. J., Brothers, G., and Sasaki, T.: Atmospheric comparison of electrochemical cell ozonesondes from different manufacturers, and with different cathode solution strengths: the Balloon Experiment on Standards for Ozonesondes, J. Geophys. Res., 113, D04307, doi:10.1029/2007JD008975, 2008a.

Deshler., T., Mercer, J. L., Smit, H. G. J., Stubi, R., Levrat, G., Johnson, B. J., Oltmans, S. J., Kivi, R., Thompson, A. M., Witte, J., Davies, J., F. J. Schmidlin and Brothers, G.: Atmospheric comparisons of electrochemical cell ozonesondes with different cathode solution strengths and from different manufacturers: a method to homogenize 0.5 and 1.0,\% KI measurements, European Geophysical Union, Vienna, Austria, April 2008, EGU2008-A-11246, 2008b.

Dietz, R. N., Pruzansky, J., and Smith, J. D.: Effect of pH on the stoichiometry of the iodometric determination of ozone, Anal. Chem., 45, 402-404, doi:10.1021/ac60324a059, 1973.

Dutsch, H. U.: Two years of regular ozone soundings over Boulder, Colorado, NCAR technical notes, NCAR/TN-10+STR, National Center for Atmospheric Resarch (US), Boulder, CO, 443 pp., 1966. 
Elliott, W. P., Ross, R. J., and Blackmore, W. H.: Recent changes in NWS upper-air observations with emphasis on changes from VIZ to Vaisala radiosondes, B. Am. Meteorol. Soc., 83, 10031017, 2002.

Emmons, L. K., Arnold, S. R., Monks, S. A., Huijnen, V., Tilmes, S., Law, K. S., Thomas, J. L., Raut, J.-C., Bouarar, I., Turquety, S., Long, Y., Duncan, B., Steenrod, S., Strode, S., Flemming, J., Mao, J., Langner, J., Thompson, A. M., Tarasick, D., Apel, E. C., Blake, D. R., Cohen, R. C., Dibb, J., Diskin, G. S., Fried, A., Hall, S. R., Huey, L. G., Weinheimer, A. J., Wisthaler, A., Mikoviny, T., Nowak, J., Peischl, J., Roberts, J. M., Ryerson, T., Warneke, C., and Helmig, D.: The POLARCAT Model Intercomparison Project (POLMIP): overview and evaluation with observations, Atmos. Chem. Phys., 15, 6721-6744, doi:10.5194/acp15-6721-2015, 2015.

Fioletov, V. E., Kerr, J. B., Wardle, D. I., Davies, J., Hare, E. W., McElroy, C. T., and Tarasick, D. W.: Long-term decline of ozone over the Canadian Arctic to early 1997 from ground-based and balloon sonde measurements, Geophys. Res. Lett., 24, 27052708, 1997.

Fioletov, V. E., Tarasick, D. W., and Petropavlovskikh, I.: Estimating ozone variability and instrument uncertainties from $\operatorname{SBUV}(/ 2)$, ozonesonde, Umkehr, and SAGE II measurements: short-term variations, J. Geophys. Res., 111, D02305, doi:10.1029/2005JD006340, 2006.

Flamm, D. L.: Analysis of ozone at low concentrations with boric acid buffered KI, Environ. Sci. Technol., 11, 978-983, 1977.

Harris, N. R. P., Hassler, B., Tummon, F., Bodeker, G. E., Hubert, D., Petropavlovskikh, I., Steinbrecht, W., Anderson, J., Bhartia, P. K., Boone, C. D., Bourassa, A., Davis, S. M., Degenstein, D., Delcloo, A., Frith, S. M., Froidevaux, L., Godin-Beekmann, S., Jones, N., Kurylo, M. J., Kyrölä, E., Laine, M., Leblanc, S. T., Lambert, J.-C., Liley, B., Mahieu, E., Maycock, A., de Mazière, M., Parrish, A., Querel, R., Rosenlof, K. H., Roth, C., Sioris, C., Staehelin, J., Stolarski, R. S., Stübi, R., Tamminen, J., Vigouroux, C., Walker, K. A., Wang, H. J., Wild, J., and Zawodny, J. M.: Past changes in the vertical distribution of ozone - Part 3: Analysis and interpretation of trends, Atmos. Chem. Phys., 15, 9965-9982, doi:10.5194/acp-15-9965-2015, 2015.

He, H., Tarasick, D. W., Hocking, W. K., Carey-Smith, T. K., Rochon, Y., Zhang, J., Makar, P. A., Osman, M., Brook, J., Moran, M. D., Jones, D. B. A., Mihele, C., Wei, J. C., Osterman, G., Argall, P. S., McConnell, J., and Bourqui, M. S.: Transport analysis of ozone enhancement in Southern Ontario during BAQS-Met, Atmos. Chem. Phys., 11, 2569-2583, doi:10.5194/acp-11-25692011, 2011.

Hering, W. S.: Ozonesonde Observations over North America, vol. 1, AFCRL-64-30(I), Air Force Cambridge Research Labs, Hanscom AFB, Bedford, MA, 1964.

Hering, W. S. and Borden, T. S.: Ozonesonde Observations over North America, vol. 2, AFCRL-64-30(II), Air Force Cambridge Research Labs, Hanscom AFB, Bedford, MA, 1964.

Hering, W. S. and Borden, T. S.: Ozonesonde Observations over North America, vol. 3, AFCRL-64-30(III), Air Force Cambridge Research Labs, Hanscom AFB, Bedford, MA, 1965.

Hering, W. S. and Borden, T. S.: Ozonesonde Observations over North America, vol. 4, AFCRL-64-30(IV), Air Force Cambridge Research Labs, Hanscom AFB, Bedford, MA, 1967.
Hilsenrath, E., Attmannspacher, W., Bass, A., Evans, W., Hagemeyer, R., Barnes, R. A., Komhyr, W., Mauersberger, K., Mentall, J., Proffitt, M., Robbins, D., Taylor, S., Torres, A., and Weinstock, E.: Results from the balloon intercomparison campaign (BOIC), J. Geophys. Res., 91, 13137-13152, 1986.

Hocking, W. K., Carey-Smith, T., Tarasick, D., Argall, S., Strong, K., Rochon, Y., Zawadzki, I., and Taylor, P.: Application of windprofiler radars to identification of stratospheric ozone intrusions and subsequent tropospheric pollution events, Nature, 450, 281-284, doi:10.1038/nature06312, 2007.

Hodgeson, J. A., Baumgardner, R. E., Martin, B. E., and Rehme, K. A.: Stoichiometry in the neutral iodometric procedure for ozone by gas-phase titration with nitric oxide, Anal. Chem., 43, 1123-1126, doi:10.1021/ac60303a026, 1971.

IPCC: Climate Change 2013: The Physical Science Basis, Contribution of Working Group I to the Fifth Assessment Report of the Intergovernmental Panel on Climate Change, edited by: Stocker, T. F., Qin, D., Plattner, G.-K., Tignor, M., Allen, S. K., Boschung, J., Nauels, A., Xia, Y., Bex, V., and Midgley, P.M., Cambridge University Press, Cambridge, United Kingdom and New York, NY, USA, 1535 pp., 2013.

Johnson, B. J., Oltmans, S. J., Vömel, H., Smit, H. G. J., Deshler, T., and Kröger, C.: Electrochemical concentration cell (ECC) ozonesonde pump efficiency measurements and tests on the sensitivity to ozone of buffered and unbuffered ECC sensor cathode solutions, J. Geophys. Res., 107, 4393, doi:10.1029/2001JD000557, 2002.

Kerr, J. B., Wardle, D. I., and Tarasick, D. W.: Record low ozone values over Canada in early 1993, Geophys. Res. Lett., 20, 1979_ 1982, 1993.

Kerr, J. B., Fast, H., McElroy, C. T., Oltmans, S. J., Lathrop, J. A., Kyro, E., Paukkunen, A., Claude, H., Köhler, U., Sreedharan, C. R., T. Takao and Tsukagoshi, Y.: The 1991 WMO international ozonesonde intercomparison at Vanscoy, Canada, Atmos. Ocean, 32, 685-716, 1994.

Kiesewetter, G., Sinnhuber, B.-M., Weber, M., and Burrows, J. P.: Attribution of stratospheric ozone trends to chemistry and transport: a modelling study, Atmos. Chem. Phys., 10, 12073-12089, doi:10.5194/acp-10-12073-2010, 2010.

Komhyr, W. D.: Electrochemical concentration cells for gas analysis, Ann. Géophys., 25, 203-210, 1969.

Komhyr, W. D.: Operations handbook - ozone measurements to 40$\mathrm{km}$ altitude with model $4 \mathrm{~A}$ electrochemical concentration cell (ECC) ozonesondes (used with 1680-MHz radiosondes), Tech. Memo. ERL ARL-149, Natl. Oceanic and Atmos. Admin., Silver Spring, MD, 1986.

Komhyr, W. D. and Harris, T. B.: Note on flow rate measurements made on Mast-Brewer ozone sensor pumps, Mon. Weather Rev., 93, 267-268, 1965.

Komhyr, W. D. and Harris, T. B.: Development of an ECCOzonesonde, NOAA Techn. Rep. ERL 200-APCL 18, USGPO, Boulder, CO, 1971.

Komhyr, W. D., Grass, R. D., and Proulx, R. A.: Ozonesonde intercomparison tests, ESSA Tech. Rep. ERL 85-APCL 4, ESSA Research Laboratories, US Dept. of Commerce, USGPO, Washington, DC, 74 pp., 1968.

Komhyr, W. D., Barnes, R. A., Brothers, G. B., Lathrop, J. A., and Opperman, D. P.: Electrochemical concentration cell ozonesonde 
performance evaluation during STOIC 1989, J. Geophys. Res., 100, 9231-9244, doi:10.1029/94JD02175, 1995.

Kopczynski, S. J. and Bufalini, J. J.: Some observations on stoichiometry of iodometric procedure analyses of ozone at $\mathrm{pH} 7.0$, Anal. Chem., 43, 1126-1127, doi:10.1021/ac60303a024, 1971.

Lanting, R. W.: Modification of the potassium iodide procedure for improved stoichiometry, Atmos. Environ., 13, 553-554, doi:10.1016/0004-6981(79)90150-1, 1979.

Lehmann, P.: An estimate of the vertical ozone profile discrepancy between the Australian Brewer-Mast and electrochemical concentration cell ozonesondes, J. Atmos. Ocean. Tech., 22, 18641874, doi:10.1175/JTECH1821.1, 2005.

Lehmann, P. and Easson, J.: A comparison of pump efficiency corrections for the Australian Brewer-Mast ozonesonde data record, J. Aust. Meteorol. Mag., 52, 259-264, 2003.

Lin, M., Fiore, A. M., Horowitz, L. W., Langford, A. O., Oltmans, S. J., Tarasick, D., and Rieder, H. E.: Climate variability modulates western U.S. ozone air quality in spring via deep stratospheric intrusions, Nat. Comm. 6, 7105, doi:10.1038/ncomms8105, 2015.

Liu, G., Tarasick, D. W., Fioletov, V. E., Sioris, C. E., and Rochon, Y. J.: Ozone correlation lengths and measurement uncertainties from analysis of historical ozonesonde data in North America and Europe, J. Geophys. Res., 114, D04112, doi:10.1029/2008JD010576, 2009.

Luers, J. K. and Eskridge, R.: Temperature corrections for the VIZ and Vaisala radiosondes, J. Appl. Meteorol., 34, 1241-1253, 1995.

Macdonald, A. M., Anlauf, K. G., Leaitch, W. R., Chan, E., and Tarasick, D. W.: Interannual variability of ozone and carbon monoxide at the Whistler high elevation site: 2002-2006, Atmos. Chem. Phys., 11, 11431-11446, doi:10.5194/acp-1111431-2011, 2011.

Manney, G. L., Santee, M. L., Rex, M., Livesey, N. J., Pitts, M. C., Veefkind, P., Nash, E. R., Wohltmann, I., Lehmann, R., Froidevaux, L., Poole, L. R., Schoeberl, M. R., Haffner, D. P., Davies, J., Dorokhov, V., Gernandt, H., Johnson, B., Kivi, R., Kyrö, E., Larsen, N., Levelt, P. F., Makshtas, A., McElroy, C. T., Nakajima, H., Parrondo, M. C., Tarasick, D. W., von der Gathen, P., Walker, K. A., and Zinoviev, N. S.: Unprecedented Arctic ozone loss in 2011, Nature, 478, 469-475, doi:10.1038/nature10556, 2011.

Mateer, C. L.: Method of evaluation of Canadian ozonesonde data, Atmospheric Environment Service Internal Report APRB 89 D 7, Environment Canada, Toronto, 31 pp., 1977.

McPeters, R. D. and Labow, G. J.: Climatology 2011: an MLS and sonde derived ozone climatology for satellite retrieval algorithms, J. Geophys. Res., 117, D10303, doi:10.1029/2011JD017006, 2012.

Morris, G., Martins, D., Thompson, A. M., Reed, A., Joseph, E., and Thompson, E.: The impact of radiosonde pressure sensor errors on ozone profiles and columns as reported by ozonesondes, 22nd Quadriennal Ozone Symposium, Toronto, Canada, 2731 August 2012, P6183, 2012.

Mueller, J. I.: Flight Preparation Instructions for the Model 7308 Ozonesonde, Mast Development Company, Davenport, Iowa, 41 pp., 1976.
Nash, J. and Schmidlin, F. J.: WMO international radiosonde comparison (UK 1984, USA 1985), WMO/TD-No. 195, 103 pp., 1987.

Nash, J., Smout, R., Oakley, T., Pathack, B., and Kurnosenko, S.: WMO intercomparison of high quality radiosonde systems, Mauritius, February 2005, WMO/TD-No. 1303, 115 pp., available at: http://www.wmo.int/pages/prog/www/IMPO/ publications/IOM-83_RSO-Mauritius/IOM-83_Radiosondes_ Vacoas2005.pdf, 2006.

Oltmans, S. J., Lefohn, A. S., Harris, J. M., Galbally, I., Scheel, H. E., Bodeker, G., Brunke, E., Claude, H., Tarasick, D., Johnson, B. J., Simmonds, P., Shadwick, D., Anlauf, K., Hayden, K., Schmidlin, F., Fujimoto, T., Akagi, K., Meyer, C., Nichol, S., Davies, J., Redondas, A., and Cuevas, E.: Long-term changes in tropospheric ozone, Atmos. Environ., 40, 3156-3173, 2006.

Oltmans, S. J., Lefohn, A. S., Harris, J. M., Tarasick, D. W., Thompson, A. M., Wernli, H., Johnson, B. J., Novelli, P. C., Montzka, S. A., Ray, J. D., Patrick, L. C., Sweeney, C., Jefferson, A., Dann, T., Davies, J., Shapiro, M., and Holben, B. N.: Enhanced ozone over western North America from biomass burning in Eurasia during April 2008 as seen in surface and profile observations, Atmos. Environ., 44, 4497-4509, doi:10.1016/j.atmosenv.2010.07.004, 2010.

Oltmans, S. J., Johnson, B. J., and Harris, J. M.: Springtime boundary layer ozone depletion at Barrow, Alaska: Meteorological influence, year to year variation, and long-term change, J. Geophys. Res., 117, D00R18, doi:10.1029/2011JD016889, 2012.

Pan, L. L., Randel, W. J., Gille, J. C., Hall, W. D., Nardi, B., Massie, S., Yudin, V., Khosravi, R., Konopka, P., and Tarasick, D.: Tropospheric intrusions associated with the secondary tropopause, J. Geophys. Res., 114, D10302, doi:10.1029/2008JD011374, 2009.

Parrington, M., Palmer, P. I., Henze, D. K., Tarasick, D. W., Hyer, E. J., Owen, R. C., Helmig, D., Clerbaux, C., Bowman, K. W., Deeter, M. N., Barratt, E. M., Coheur, P.-F., Hurtmans, D., Jiang, Z., George, M., and Worden, J. R.: The influence of boreal biomass burning emissions on the distribution of tropospheric ozone over North America and the North Atlantic during 2010, Atmos. Chem. Phys., 12, 2077-2098, doi:10.5194/acp-12-20772012, 2012.

Pitts, J. N., McAfee, J. M., Long, W. D., and Winer, A. M.: Longpath infrared spectroscopic investigation at ambient concentrations of the $2 \%$ neutral buffered potassium iodide method for determination of ozone, Environ. Sci. Technol., 10, 787-793, 1976.

Regener, V.: On a sensitive method for the recording of atmospheric ozone, J. Geophys. Res., 65, 3975-3977, 1960.

Richner, H. and Phillips, P. D.: Reproducibility of VIZ radiosonde data and some sources of error, J. Appl. Meteorol., 20, 954-962, 1981.

Saltzman, B. E. and Gilbert, N.: Iodometric microdetermination of organic oxidants and 696 ozone. Resolution of mixtures by kinetic colourimetry, Anal. Chem., 31, 1914-1920, 1959.

Schmidlin, F. J.: WMO international radiosonde intercomparison. Phase II: Wallops Island, Virginia, USA, 1985, WMO/TD-No. 312, 113 pp., 1988.

Smit, H. G. J. and ASOPOS-panel: Quality assurance and quality control for ozonesonde measurements in GAW, WMO Global Atmosphere Watch report series, No. 121, 100 pp., World 
Meteorological Organization, GAW Report No. 201, 100 pp., Geneva, available at: http://www.wmo.int/pages/prog/arep/gaw/ documents/GAW_201.pdf, 2011.

Smit, H. G. J. and Kley, D.: JOSIE: the 1996 WMO International intercomparison of ozonesondes under quasi flight conditions in the environmental simulation chamber at Jülich, WMO Global Atmosphere Watch Report No. 130, WMO TD No. 926, World Meteorological Organization, Geneva, 1998.

Smit, H. G. J., Sträter, W., Helten, M., Kley, D., Ciupa, D., Claude, H. J., Köhler, U., Hoegger, B., Levrat, G., Johnson, B., Oltmans, S. J., Kerr, J. B., Tarasick, D. W., Davies, J., Shitamichi, M., Srivastav, S. K., and Vialle, C.: JOSIE: the 1996 WMO international intercomparison of ozonesondes under quasi-flight conditions in the environmental chamber at Jülich, in: Proc. Quadrennial Ozone Symposium 1996, l'Aquila, Italy, edited by: Bojkov, R. D. and Visconti, G., Parco Sci. e Tecnol. d'Abruzzo, Italy, 971-974, 1996.

Smit, H. G. J., Straeter, W., Johnson, B., Oltmans, S., Davies, J., Tarasick, D. W., Hoegger, B., Stubi, R., Schmidlin, F., Northam, T., Thompson, A., Witte, J., I. Boyd and F. Posny: Assessment of the performance of ECC-ozonesondes under quasi-flight conditions in the environmental simulation chamber: insights from the Juelich Ozone Sonde Intercomparison Experiment (JOSIE), J. Geophys. Res., 112, D19306, doi:10.1029/2006JD007308, 2007.

Smit, H., Oltmans, S., Deshler, T., Tarasick, D., Johnson, B., Schmidlin, F., Stuebi, R., and Davies, J.: SI2N/O3S-DQA Activity: Guide Lines for Homogenization of Ozone Sonde Data (Version 2.0: 19 November 2012), available at: https://dl.dropboxusercontent. com/u/1742024/Profession/WCCOS-JOSIE/O3S-DQA/ O3S-DQA-GuidelinesHomogenization-V2-19November2012. pdf, 2012.

Stauffer, R. M., Morris, G. A., Thompson, A. M., Joseph, E., Coetzee, G. J. R., and Nalli, N. R.: Propagation of radiosonde pressure sensor errors to ozonesonde measurements, Atmos. Meas. Tech., 7, 65-79, doi:10.5194/amt-7-65-2014, 2014.

Steinbrecht, W., Schwarz, R., and Claude, H.: New pump correction for the Brewer-Mast ozone sonde: determination from experiment and instrument intercomparisons, J. Atmos. Ocean. Tech., 15, 144-156, doi:10.1175/15200426(1998)015<0144:NPCFTB>2.0.CO;2, 1998.

Steinbrecht, W., Claude, H., Schönenborn, F., Leiterer, U., Dier, H., and Lanzinger, E.: Pressure and temperature differences between Vaisala RS80 and RS92 radiosonde systems, J. Atmos. Ocean. Tech., 25, 909-927, doi:10.1175/2007JTECHA999.1, 2008.

Tarasick, D. W. and Bottenheim, J. W.: Surface ozone depletion episodes in the Arctic and Antarctic from historical ozonesonde records, Atmos. Chem. Phys., 2, 197-205, doi:10.5194/acp-2197-2002, 2002.

Tarasick, D. W., Kerr, J. B., Wardle, D. I., Bellefleur, J. J., and Davies, J.: Tropospheric ozone trends over Canada: 1980-1993, Geophys. Res. Lett., 22, 409-412, 1995.

Tarasick, D. W., Davies, J., Anlauf, K., Watt, M., Steinbrecht, W., and Claude, H. J.: Laboratory investigations of the response of Brewer-Mast sondes to tropospheric ozone, J. Geophys. Res., 107, 4308, doi:10.1029/2001JD001167, 2002.

Tarasick, D. W., Fioletov, V. E., Wardle, D. I., Kerr, J. B., and Davies, J.: Changes in the vertical distribution of ozone over
Canada from ozonesondes: 1980-2001, J. Geophys. Res., 110, D02304, doi:10.1029/2004JD004643, 2005.

Tarasick, D. W., Moran, M. D., Thompson, A. M., Carey-Smith, T., Rochon, Y., Bouchet, V. S., Gong, W., Makar, P. A., Stroud, C., Ménard, S., Crevier, L.-P., Cousineau, S., Pudykiewicz, J. A., Kallaur, A., Moffet, R., Ménard, R., Robichaud, A., Cooper, O. R., Oltmans, S. J., Witte, J. C., Forbes, G., Johnson, B. J., Merrill, J., Moody, J. L., Morris, G., Newchurch, M. J., Schmidlin, F. J., and Joseph, E.: Comparison of Canadian Air Quality Forecast Models With Tropospheric Ozone Profile Measurements Above Mid-Latitude North America During the IONS/ICARTT Campaign: Evidence for Stratospheric Input, J. Geophys. Res., 112, D12S22, doi:10.1029/2006JD007782, 2007.

Tarasick, D. W., Lukovich, J., Moeini, O., Osman, M., and Liu, J. J.: Arctic surface ozone depletions from ozone soundings, 13th Quadrennial iCACGP Symposium \& 13th IGAC Science Conference, Natal, Brazil, 22-26 September 2014, P1.56, 2014.

Thiébaux, H. J. and Zwiers, F. W.: The interpretation and estimation of effective sample size, J. Clim. Appl. Meteorol., 23, 800-811, 1984.

Thompson, A. M., Stone, J. B., Witte, J. C., Miller, S., Oltmans, S. J., Kucsera, T. L., Merrill, J. T., Forbes, G., Tarasick, D. W., Joseph, E., Schmidlin, F. J., MacMillan, W. W., Warner, J., Hintsa, E., and Johnson, J.: Intercontinental Chemical Transport Experiment Ozonesonde Network Study (IONS): 2. Tropospheric ozone budgets and variability over northeastern North America, J. Geophys. Res., 112, D12S13, doi:10.1029/2006JD007670, 2007.

Thornton, D. C. and Niazy, N.: Sources of background current in the ECC ozonesonde: implications for total ozone measurements, J. Geophys. Res., 87, 8943-8950, 1982.

Thornton, D. C. and Niazy, N.: Effects of solution mass transport on the ECC ozonesonde background current, Geophys. Res. Lett., 10, 148-151, 1983.

Torres, A.: ECC performance at high altitudes: pump efficiency, NASA Tech. Memo., TM93290, 10 pp., 1981.

Walker, T. W., Martin, R. V., van Donkelaar, A., Leaitch, W. R., MacDonald, A. M., Anlauf, K. G., Cohen, R. C., Bertram, T. H., Huey, L. G., Avery, M. A., Weinheimer, A. J., Flocke, F. M., Tarasick, D. W., Thompson, A. M., Streets, D. G., and Liu, X.: TransPacific transport of reactive nitrogen and ozone to Canada during spring, Atmos. Chem. Phys., 10, 8353-8372, doi:10.5194/acp10-8353-2010, 2010.

Walker, T. W., Jones, D. B. A., Parrington, M., Henze, D. K., Murray, L. T., Bottenheim, J. W., Anlauf, K., Worden, J. R., Bowman, K. W., Shim, C., Singh, K., Kopacz, M., Tarasick, D. W., Davies, J., von der Gathen, P., and Carouge, C. C.: Impacts of midlatitude precursor emissions and local photochemistry on ozone abundances in the Arctic, J. Geophys. Res., 117, D01305, doi:10.1029/2011JD016370, 2012.

Wang, J. and Young, K.: Comparisons of 7-year radiosonde data from two neighboring stations and estimation of random error variances for four types of radiosondes, 13th Symposium on Meteorological Observations and Instrumentation, Savannah, GA, USA, 19-23 June 2005, 2005.

WMO (World Meteorological Organization): International meteorological vocabulary, WMO Rep. 182, World Meteorol. Org., Geneva, Switzerland, 784 pp., ISBN: 92-63-02182-1, 1992. 
WMO (World Meteorological Organization): Scientific Assessment of Ozone Depletion: 2014, World Meteorological Organization, Global Ozone Research and Monitoring Project - Report No. 55, Geneva, 416 pp., 2014.
Zwiers, F. W. and von Storch, H.: Taking serial correlation into account in tests of the mean, J. Climate, 8, 336-351, 1995. 